\title{
Spawning strategies of fishes in relation to circulation, phytoplankton production, and pulses in zooplankton off the northeastern United States*
}

\author{
K. Sherman ${ }^{1}$, W. Smith ${ }^{2}$, W. Morse ${ }^{2}$, M. Berman ${ }^{1}$, J. Green $^{1}$ and L. Ejsymont ${ }^{3}$ \\ ${ }^{1}$ National Oceanic and Atmospheric Adminıstration, National Marine Fisheries Service, Nor?heast Fisheries Center, \\ Narragansett Laboratory, Narragansett, Rhode Island 02882, USA \\ ${ }^{2}$ National Oceanic and Atmospheric Administration, National Marine Fisheries Service, Northeast Fisheries Center, \\ Sandy Hook Laboratory, Highlands, New Jersey 07732, USA \\ ${ }^{3}$ Sea Fisheries Institute, Szczecin, Poland
}

\begin{abstract}
Spatial and temporal distribution patterns of larval fishes are analyzed in relation to circulation, phytoplankton production, and pulses in abundance of zooplankton in continental shelf waters between Cape Hatteras and Cape Sable. Our analyses are based on 4 yr (1977-80) of joint international ichthyoplankton surveys covering $260,000 \mathrm{~km}^{2}$ of the northeast shelf. Spawning strategies ase related to topographic features and circulation which in turn play a key role in maintenance of the stocks. Peak spawning for several important species is shown to be in synchrony with increasing abundance levels of their seasonally-dominant copepod prey. Other species have developed a ubiquitous spawning strategy producing larvae over a protracted time period in the entire northeastern shelf area, allowing these populations to increase rapidly in response to favorable conditions.
\end{abstract}

\section{INTRODUCTION}

Ichthyoplankton surveys represent an effective sampling strategy for measuring the spawning-stock abundance of commercially important fish species inhabiting large marine ecosystems (Smith and Richardson, 1977; Berrien et al., 1981; Saville, 1981; Saville and Schnack, 1981). They also serve as an effective means for measuring shifts in the abundance of species within a finfish community (Sherman et al., 1981a; Morse, 1982). In this study we examine the relation between larval fish abundance, circulation, primary production, and seasonal pulses in zooplankton of the northeastern shelf of the USA.

Our study of spawning strategies was directed to an examination of the more important fish species based on observed larval distribution patterns. The results are based on 4 yr (1977-1980) of ichthyoplankton surveys conducted by the United States, Poland, and the Soviet Union as part of a joint study of the biological and physical limits to fish production in a continental shelf ecosystem. The study, known as MARMAP, mea-

- MARMAP Contribution MED/NEFC 83-01 sures changes in key structural components of large marine ecosystems (Sherman, 1980). Systematic MARMAP surveys are conducted over the northeast continental shelf measuring spatial and temporal changes in ichthyoplankton, primary production $\left({ }^{14} \mathrm{C}\right)$, chlorophyll a, phaeophytin, nutrients $\left(\mathrm{NO}_{2}, \mathrm{NO}_{3}, \mathrm{NH}_{4}, \mathrm{PO}_{4}\right)$; zooplankton, fish, benthos, sea-birds, water-column temperature, salinity, and circulation. Earlier studies of the ichthyoplankton of the region have generally been conducted over limited geographic areas for relatively short periods of time (Marak and Colton, 1961; Marak et al., 1962a, b; Colton and St. Onge, 1974; Smith et al., 1975; Lough et al., 1981; Obenchain, 1981; Graham, 1982; Townsend, 1984).

\section{STUDY AREA}

The study area includes the shelf from the Gulf of Maine to Cape Hatteras. The Gulf of Maine is bordered by Nova Scotia to the east, the coasts of New Brunswick and New England to the north and west. On the southern boundary of the Gulf of Maine is Georges Bank - a broad, shallow plateau. The northern and 
eastern sides of the bank are separated from the Scotian Shelf and the Gulf of Maine by the deep Northeast Channel (Emery and Uchupi, 1972). The Southern New England subarea is bounded on the east by the Great South Channel, on the west by the Hudson Trough. South of New England on the west side of Great South Channel is Nantucket Shoals where water depths shallower than $10 \mathrm{~m}$ are common. Further to the west in the Mid-Atlantic Bight the continental shelf slopes gently from the coast to the shelf break. At the apex of the Bight, the Hudson Canyon cuts across the shelf and marks a change in shelf orientation toward the southwest to Cape Hatteras. The shelf in this region narrows toward the south and includes the mouths of the Delaware and Chesapeake Bays (Fig. 1a).

The average circulation off the northeastern USA involves seasonally variable gyres in the Gulf of Maine and on Georges Bank (Butman et al., 1982; Ingham et al., 1982). The Gulf of Maine gyre is cyclonic and is most pronounced during spring and summer. The gyre on Georges Bank is anticyclonic and is most highly developed in spring and summer. Off Southern New
England the shelf water flows slowly westward, then southwestward on the continental shelf in the MidAtlantic Bight. Similarly, slow southwestward flow occurs in slope waters which occasionally carry one or more Gulf Stream warm core rings. Beyond the slope waters, the Gulf Stream meanders in a northeasterly direction (Fig. 1b).

\section{METHODS}

The MARMAP survey area encompasses some $260,000 \mathrm{~km}^{2}$. Sampling locations were spaced at 8 to $18 \mathrm{~km}$ intervals along 7 transects; additional stations were chosen from a stratified-random design used for research trawl surveys (Grosslein, 1969), with station intervals of 25 to $35 \mathrm{~km}$ (Fig. 2). From 1977 through 1980 we conducted 26 surveys and with repeated coverage occupied 3,895 stations (Table 1).

Niskin bottle casts provided water samples for measuring nutrients, chlorophyll $a$ and phaeophytin $a$, ${ }^{14} \mathrm{C}$ primary production, temperature, salinity and dis-
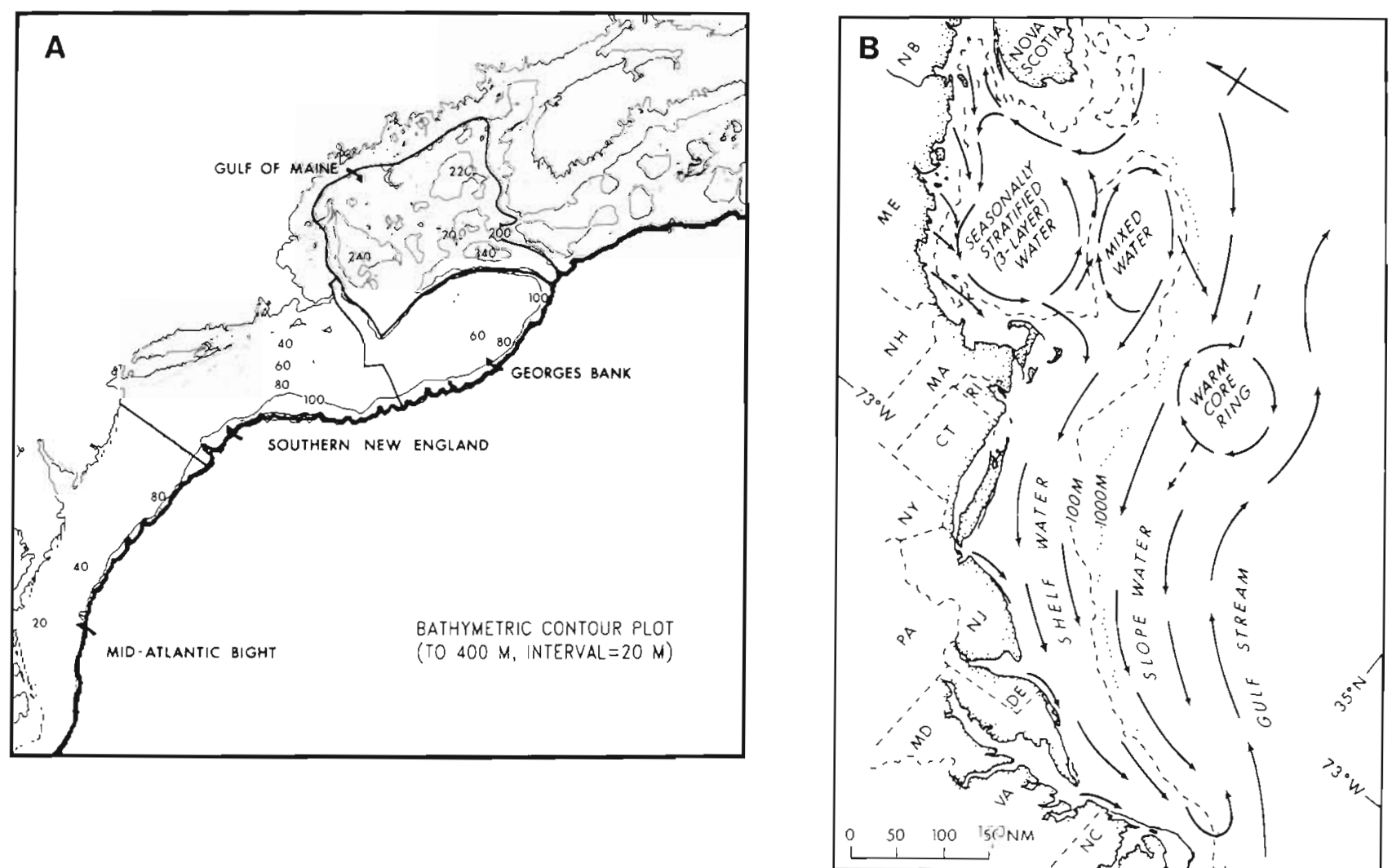

Fig. 1. Bathymetry (A) and surface circulation (B) of the 4 subareas of the shelf - Gulf of Maine (GOM), Georges Bank (GB), Southern New England (SNE), Mid-Atlantic Bight (MAB). Northern sector of shelf ecosystem characterized by cyclonic gyre and seasonally stratified 3-layered water mass, over the deep basins of GOM; and mixed water and anticyclonic gyre over shoal coarse sand bottom of GB. Further south the waters move southwesterly along the broad shelf of SNE to the narrower gentlysloping shelf plain of $\mathrm{MAB}$ which is influenced by large-scale estuarine runoff from Hudson, Delaware, and Chesapeake estuaries 
solved oxygen. Shipboard sample preparation techniques, and subsequent laboratory procedures for phytoplankton samples are described by Evans and O'Reilly (in press).

Plankton samples were collected by double-oblique tows with a $61 \mathrm{~cm}$ bongo fitted with 0.333 and 0.505 $\mathrm{mm}$ mesh nets (Posgay and Marak, 1980). The $0.505 \mathrm{~mm}$ mesh samples were used for studies of fish eggs and larvae. Larvae retained by this net ranged in length from 3.5 to $28.0 \mathrm{~mm}$. The $0.333 \mathrm{~mm}$ mesh samples were used for invertebrate zooplankton studies. A $20 \mathrm{~cm}$ bongo fitted with smaller mesh nets $(0.165$ and $0.253 \mathrm{~mm}$, or 0.053 and $0.165 \mathrm{~mm}$ ) was towed along with the larger sampler at selected stations to sample planktonic organisms that pass through the $0.333 \mathrm{~mm}$ net. The bongo array was lowered to within a few meters of the bottom or to a maximum depth of $200 \mathrm{~m}$ at $50 \mathrm{~m} \mathrm{~min}^{-1}$ and retrieved at $20 \mathrm{~m} \mathrm{~min}^{-1}$. Ship speed varied between 1 and 2 knots to maintain a $45^{\circ}$ wire angle during a tow. A flow meter in the mouth of each net measured the amount of water filtered during a tow, and a bathykymograph recorded tow profiles. Plankton samples were preserved in $4 \%$ buffered Formalin

Organisms from the $61 \mathrm{~cm}$ bongo samples were sorted, identified and enumerated at the Plankton Sorting and Identification Center at Szczecin, Poland. Fish eggs and larvae and corresponding logs for ichthyoplankton and zooplankton were returned to the Northeast Fisheries Center for archiving and data processing.

Zooplankton biomass is expressed as displacement volumes per $100 \mathrm{~m}^{3}$ of water sampled. The fish larvae at each station are standardized to the number under $10 \mathrm{~m}^{2}$ surface area. The $\Delta$-distribution (Aitchison, 1955 ) is used to provide unbiased estimates of the sample means. The application of the $\Delta$-distribution to survey data is presented by Berrien et al. (1981) and Pennington (1983).

\section{RESULTS}

\section{Primary production}

The continental shelf from the Gulf of Maine to Cape Hatteras is highly productive. Estimates of primary production for the MARMAP surveys are highest from May to August and lowest from December to February. The mean annual rate of primary production ranges from $260 \mathrm{~g} \mathrm{C} \mathrm{m}^{-2} \mathrm{yr}^{-1}$ on the mid-shelf off the Maryland-Virginia coast to $470 \mathrm{~g} \mathrm{C} \mathrm{m}^{-2} \mathrm{yr}^{-1}$ on Georges Bank (Fig. 3). Production estimates at the offings of the major estuaries (e.g. Hudson, Delaware, Chesapeake) exceed $350 \mathrm{~g} \mathrm{C} \mathrm{m}^{-2} \mathrm{yr}^{-1}$ (O'Reilly and Busch, 1983)

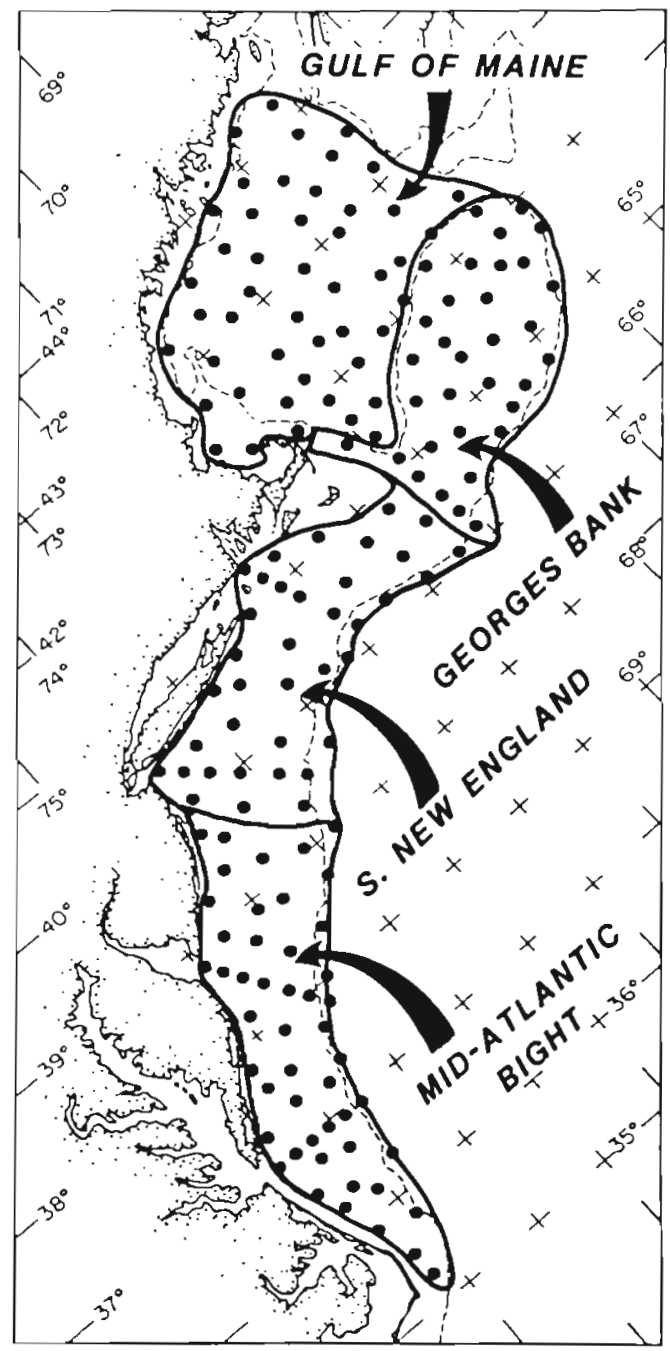

Fig. 2. MARMAP survey area and station locations (dots) off the northeastern coast of the United States. The 4 subareas of the shelf sampled include Gulf of Maine (GOM), Georges Bank (GB), Southern New England (SNE), and Mid-Atlantic Bight (MAB)

\section{Zooplankton}

In each subarea of the shelf the temporal pulses in plankton volumes were similar among $5 \mathrm{yr}$ of MARMAP zooplankton surveys (1977-1981) with distinct seasonal patterns in each of the four subareas (Sherman et al., 1983). The early spring peak on Georges Bank is followed by a sharp decline from late spring through summer (Fig. 4). In the Gulf of Maine zooplankton volumes and copepod cohort production increase in early spring and are maintained at a high level through early autumn. In Southern New England waters the greatest seasonal zooplankton pulse is from winter to spring, followed by a decline in summer and a secondary peak in early autumn. Further south, along the shelf in the Mid-Atlantic Bight, zooplankton 
Table 1. Summary of MARMAP ichthyoplankton survey seasons, dates, vessels, and number of stations sampled, 1977-80

\begin{tabular}{|c|c|c|c|c|c|}
\hline Year & Season & Date & Vessel & Cruise & No. sta \\
\hline \multirow[t]{10}{*}{1977} & Late winter & $13 \mathrm{Feb}-8 \mathrm{Apr}$ & $\begin{array}{l}\text { MOUNT MITCHELL } \\
\text { DELAWARE II }\end{array}$ & $\begin{array}{l}77-01 \\
77-03\end{array}$ & 182 \\
\hline & Late winter & $5 \mathrm{Mar}-22 \mathrm{Apr}$ & $\begin{array}{l}\text { GOERLITZ } \\
\text { DELAWARE II }\end{array}$ & $\left.\begin{array}{l}77-01 \\
77-04 \text { I }\end{array}\right\}$ & 185 \\
\hline & Early spring & $14 \mathrm{Apr}-13 \mathrm{May}$ & $\begin{array}{l}\text { ALBATROSS IV } \\
\text { DELAWARE II }\end{array}$ & $\left.\begin{array}{l}77-02 \\
77-05 \text { I }\end{array}\right\}$ & 189 \\
\hline & Spring & 18 May-22 Jun & DELAWARE II & $77-05$ II & \\
\hline & & & NOGLIKI & $77-02$ & 197 \\
\hline & & & DELAWARE II & $77-07 \mathrm{I}$ & \\
\hline & Summer & $30 \mathrm{JuI}-1 \mathrm{Sep}$ & YUBILEINIY & $77-02$ & 160 \\
\hline & & & DELAWARE II & $77-09$ & 100 \\
\hline & Autumn & 7 Oct-9 Nov & ARGUS & $77-01$ & 142 \\
\hline & Late autumn & 13 Nov-13 Dec & $\begin{array}{l}\text { MOUNT MITCHELL } \\
\text { KELEZ }\end{array}$ & $\begin{array}{l}77-11 \\
77-11\end{array}$ & 90 \\
\hline \multirow[t]{9}{*}{1978} & Late winter & 15 Feb-16 Mar & $\begin{array}{l}\text { ALBATROSS IV } \\
\text { DELAWARE II }\end{array}$ & $\begin{array}{l}78-02 \\
78-02\end{array}$ & 185 \\
\hline & Spring & $18 \mathrm{Apr}-23 \mathrm{May}$ & ARGUS & $78-04$ & 175 \\
\hline & & & ALBATROSS IV & $78-04$ & 1) \\
\hline & Early summer & 24 Jun-16 Jul & ALBATROSS IV & $78-07$ & 143 \\
\hline & Summer & 12 Aug-4 Sep & BELOGORSK & $78-01$ & 152 \\
\hline & Early autumn & 6 Oct-11 Nov & WIECZNO & $78-04$ & \\
\hline & & & BELOGORSK & $78-03$ & 156 \\
\hline & & & DELAWARE II & $78-06$ & \\
\hline & Autumn & $16-29 \mathrm{Nov}$ & BELOGORSK & $78-04$ & 74 \\
\hline \multirow[t]{7}{*}{1979} & Late winter & $25 \mathrm{Feb}-14 \mathrm{Mar}$ & DELAWARE II & $79-03$ & 102 \\
\hline & Early spring & 1 Apr-7 May & ALBATROSS IV & $79-03$ & 105 \\
\hline & & & DELAWARE II & $\begin{array}{l}79-04 \\
79-05\end{array}$ & 170 \\
\hline & $\begin{array}{l}\text { Spring } \\
\text { Early summer }\end{array}$ & $\begin{array}{l}\text { 6-29 May } \\
17 \text { Jun-12 Jul }\end{array}$ & $\begin{array}{l}\text { DELAWARE II } \\
\text { ALBATROSS IV }\end{array}$ & $\begin{array}{l}79-05 \\
79-06\end{array}$ & 123 \\
\hline & Summer & 11 Aug-2 Sep & BELOGORSK & $79-01$ & 144 \\
\hline & Early autumn & $4-28$ Oct & ALBATROSS IV & $79-11$ & 161 \\
\hline & Late autumn & 15 Nov-20 Dec & ALBATROSS IV & $79-13$ & 105 \\
\hline \multirow[t]{10}{*}{1980} & Late winter & $20 \mathrm{Feb}-4$ Apr & ALBATROSS IV & $\begin{array}{l}80-02 \\
80-02\end{array}$ & 170 \\
\hline & Early spring & 16 Apr-12 May & $\begin{array}{l}\text { WIECZNO } \\
\text { EVRIKA }\end{array}$ & $\begin{array}{l}80-02 \\
80-01\end{array}$ & \\
\hline & & & DELAWARE II & $80-02$ & 174 \\
\hline & & & ALBATROSS IV & $80-03$ II & \\
\hline & Late spring & 23 May-29 Jun & DELAWARE II & $80-03$ & 148 \\
\hline & & & EVRIKA & $80-04$ & 148 \\
\hline & Summer & 16 Jul-9 Aug & EVRIKA & $80-06$ & 152 \\
\hline & & & DELAWARE II & $80-05$ & 102 \\
\hline & Early autumn & $26 \mathrm{Sep}-29$ Oct & ALBATROSS IV & $80-10$ & 174 \\
\hline & Late autumn & 19 Nov-21 Dec & ALBATROSS IV & $80-12$ & 137 \\
\hline
\end{tabular}

abundance increases from a low in winter to an annual peak in autumn. The seasonal ranges in zooplankton volumes and the dominant species were similar to the levels of abundance and species composition observed in the early decades of the century, suggesting that unlike the Northeast Atlantic, zooplankton off the northeastern USA coast has not undergone any major changes for the past $70 \mathrm{yr}$ (Sherman et al., 1983).

\section{Ichthyoplankton species composition}

The mean percentage composition of the ichthyoplankton species in the 4 yr collection was determined for each of the seasons (winter, Jan-Mar; spring, AprJun; summer, Jul-Sep; autumn, Oct-Dec). The size of larvae in our collections ranged in length from 3.5 to $28.0 \mathrm{~mm}$. In winter, sand eel Ammodytes sp. is the predominant species in all 4 subareas. The only other species of consequence are pollock Pollachius virens in the Gulf of Maine, and cod Gadus morhua on Georges Bank. All other species constitute less than $10 \%$ of the total (Table 2).

The number of taxa in the ichthyoplankton increases in spring, ranging from 41 in the Gulf of Maine to 107 in the Mid-Atlantic Bight. The more abundant species are sand eel and haddock Melanogrammus aeglefinus 
Fig. 3. Mean annual primary production on the northeast continental shelf in $\mathrm{g} \mathrm{C} \mathrm{m}^{-2} \mathrm{yr}^{-1}$. (After

O'Reilly and Busch, 1983)

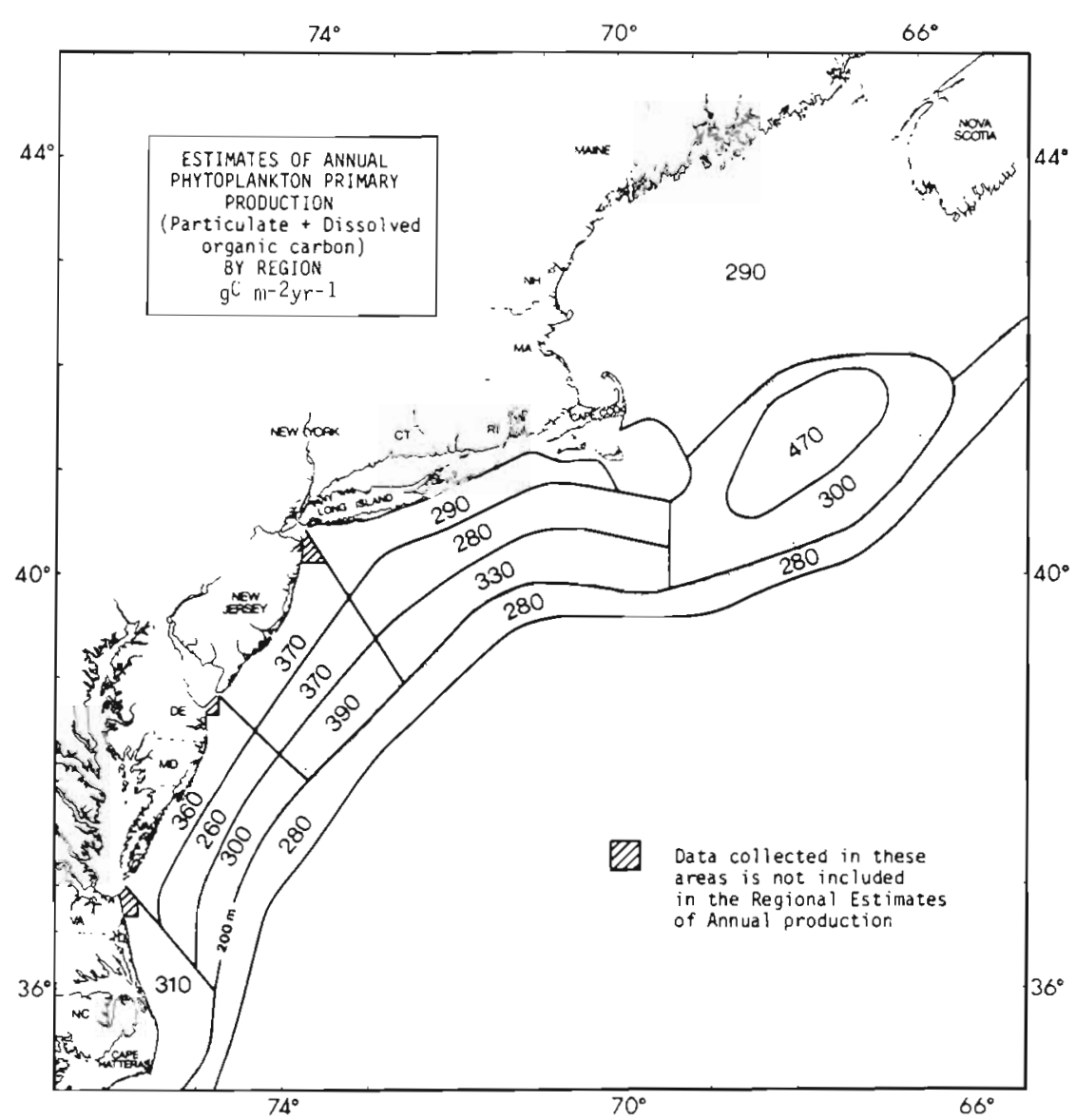

Among the abundant species in the Gulf of Maine are redfish Sebastes spp., cunner Tautogolabrus adspersus, and hakes Urophycis spp. Silver hake Merluccius bilinearis and other hakes predominate on Georges Bank and in Southern New England waters. In the Mid-Atlantic Bight smallmouth flounder Etropus microstomus, Gulf Stream flounder Citharichthys arcti-
Fig. 4. Seasonal trends in zooplankton standing stock for Gulf of Maine, Georges Bank, Southern New England, and Mid-Atlantic Bight. Seasonal means for 1977-81 in solid lines. Plotted with confidence intervals of \pm 1 standard error (dashed line). (Adapted from Sheminan et al., 1983)

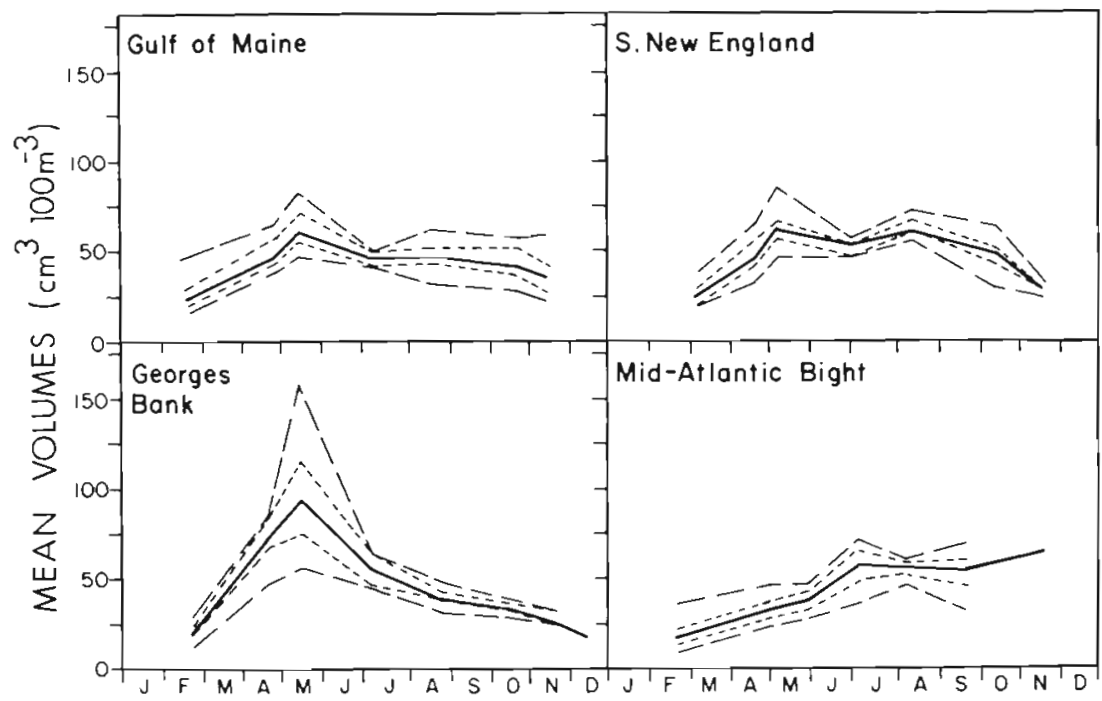


Table 2. Percentage composition of all larval fish species in MARMAP collections on the northeastern continental shelf (1977-1980)

\begin{tabular}{|c|c|c|c|c|c|}
\hline Rank & Species & $\%$ & Rank & Species & $\%$ \\
\hline \multicolumn{6}{|c|}{ Winter } \\
\hline & GULF OF MAINE & & & GEORGES BANK & \\
\hline 1 & Sand eel Ammodytes sp. & 73.87 & 1 & Sand eel Ammodytes sp. & 63.51 \\
\hline 2 & Pollock Pollachius virens & 11.52 & 2 & Atlantic cod Gadus morhua & 21.40 \\
\hline 3 & Atlantic herring Clupea harengus & 3.91 & 3 & Haddock Melanogrammus aeglefinus & 6.79 \\
\hline 4 & Snakeblenny Lumpenus lumpretaeformis & 2.98 & 4 & Witch flounder Glyptocephalus cynoglossus & 1.75 \\
\hline 5 & Rock gunnel Pholis gunnellus & 2.93 & 5 & Pollock Pollachius virens & 1.03 \\
\hline 6 & Sculpins Cottidae & 2.38 & 6 & & $<1.00$ \\
\hline 7 & & $<1.00$ & $\downarrow$ & & $\downarrow$ \\
\hline$\downarrow$ & & $\downarrow$ & 26 & & \\
\hline \multicolumn{6}{|l|}{13} \\
\hline & SOUTHERN NEW ENGLAND & & & MID-ATLANTIC BIGHT & \\
\hline 1 & Sand eel Ammodytes sp. & 98.70 & 1 & Sand eel Ammodytes sp. & 96.57 \\
\hline 2 & & $<1.00$ & 2 & & $<1.00$ \\
\hline$\downarrow$ & & $\downarrow$ & $\downarrow$ & & $\downarrow$ \\
\hline 25 & & & 59 & & \\
\hline \multicolumn{6}{|c|}{ Spring } \\
\hline & GULF OF MAINE & & & GEORGES BANK & \\
\hline 1 & Sand eel Ammodytes sp. & 48.66 & 1 & Haddock Melanogrammus aeglefinus & 58.39 \\
\hline 2 & Haddock Melanogrammus aeglefinus & 13.08 & 2 & Atlantic cod Gadus morhua & 19.61 \\
\hline 3 & American plaice Hippoglossoides platessoides & 6.33 & 3 & American plaice Hippoglossoides platessoides & 4.99 \\
\hline 4 & Snailfishes Cyclopteridae & 5.71 & 4 & Lanternfish Benthosema glaciale & 4.69 \\
\hline 5 & Atlantic cod Gadus morhua & 4.75 & 5 & Redfish Sebastes sp. & 1.84 \\
\hline 6 & Redfish Sebastes sp. & 3.79 & 6 & Yellowtail flounder Limanda ferruginea & 1.72 \\
\hline 7 & Rock gunnel Pholis gunnellus & 2.91 & 7 & Sculpins Cottidae & 1.60 \\
\hline 8 & Snakeblenny Lumpenus lumpretaeformis & 1.93 & 8 & Sand eel Ammodytes sp. & 1.24 \\
\hline 9 & Offshore hake Merluccius albidus & 1.80 & 9 & Winter flounder Pseudopleuronectes americanus & 1.16 \\
\hline 10 & Lanternfish Benthosema glaciale & 1.27 & 10 & Snailfishes, Cyclopteridae & 1.03 \\
\hline 11 & Sculpins, Cottidae & 1.05 & 11 & & $<1.00$ \\
\hline 12 & & $<1.00$ & $\downarrow$ & & $\downarrow$ \\
\hline$\downarrow$ & & $\downarrow$ & & & \\
\hline \multicolumn{6}{|l|}{41} \\
\hline & SOUTHERN NEW ENGLAND & & & MID-ATLANTIC BIGHT & \\
\hline 1 & Sand eel Ammodytes sp. & 38.92 & 1 & Lanternfish Benthosema glaciale & 43.87 \\
\hline 2 & Atlantic mackerel Scomber scombrus & 17.27 & 2 & Atlantic mackerel Scomber scombrus & 10.48 \\
\hline 3 & Lanternfish Benthosema glaciale & 14.24 & 3 & Sand eel Ammodytes sp. & 5.64 \\
\hline 4 & Yellowtail flounder Limanda ferruginea & 7.91 & 4 & Windowpane Scophthalmus aquosus & 4.46 \\
\hline 5 & Haddock Melanogrammus aeglefinus & 6.95 & 5 & Butterfish Peprilus triacanthus & 3.79 \\
\hline 6 & Snailfish Liparis sp. & 1.86 & 6 & Yellowtail flounder Limanda ferruginea & 3.19 \\
\hline 7 & Atlantic cod Gadus morhua & 1.75 & 7 & Lizardfishes, Synodontidae & 2.87 \\
\hline 8 & Snailfishes, Cyclopteridae & 1.62 & 8 & Cusk eels, Ophidiidae & 2.23 \\
\hline 9 & & $<1.00$ & 9 & Flounders, Bothidae & 1.58 \\
\hline$\downarrow$ & & $\downarrow$ & 10 & Lanternfishes, Myctophidae & 1.22 \\
\hline \multirow[t]{5}{*}{44} & & & 11 & Goosefish Lophius americanus & 1.10 \\
\hline & & & 12 & Gulf Stream flounder Citharichthys arctifrons & 1.08 \\
\hline & & & 13 & & $<1.00$ \\
\hline & & & $\downarrow$ & & $\downarrow$ \\
\hline & & & 107 & & \\
\hline \multicolumn{6}{|c|}{ Summer } \\
\hline & GULF OF MAINE & & & GEORGES BANK & \\
\hline 1 & Redfish Sebastes sp. & 51.45 & 1 & Silver hake Merluccius bilinearis & 60.10 \\
\hline 2 & Cunner Tautogolabrus adspersus & 20.00 & 2 & Hakes Urophycis spp. & 27.53 \\
\hline 3 & Hakes Urophycis spp. & 15.12 & 3 & Yellowtail flounder Limanda ferruginea & 4.02 \\
\hline 4 & Silver hake Merluccius bilinearis & 5.42 & 4 & Offshore hake Merluccius albidus & 3.54 \\
\hline 5 & Butterfish Peprilus triacanthus & 1.78 & 5 & Fourspot flounder Hippoglossina oblonga & 1.55 \\
\hline 6 & Fourbeard rockling Enchelyopus cimbrius & 1.35 & 6 & & $<1.00$ \\
\hline 7 & & $<1.00$ & $\downarrow$ & & $\downarrow$ \\
\hline$\downarrow$ & & $\downarrow$ & 35 & & \\
\hline 23 & & & & & \\
\hline
\end{tabular}


Table 2. Continued

\begin{tabular}{|c|c|c|c|c|c|}
\hline Rank & Species & $\%$ & Rank & Species & $\%$ \\
\hline \multicolumn{6}{|c|}{ Summer } \\
\hline & SOUTHERN NEW ENGLAND & & & MID-ATLANTIC BIGHT & \\
\hline 1 & Hakes Urophycis spp. & 63.04 & 1 & Smallmouth flounder Etropus microstomus & 22.78 \\
\hline 2 & Silver hake Merluccius bilinearis & 15.93 & 2 & Gulf Stream flounder Cithanichthys arctifrons & 12.33 \\
\hline 3 & Butterfish Peprilus triacanthus & 3.84 & 3 & Anchovies Engraulidae & 11.72 \\
\hline 4 & Gulf Stream flounder Citharichthys arctifrons & 3.81 & 4 & Bluefish Pomatomus saltatrix & 8.05 \\
\hline 5 & Cunner Tautogolabrus adspersus & 3.19 & 5 & Butterfish Peprilus triacanthus & 6.83 \\
\hline 6 & Fourspot flounder Hippoglossina oblonga & 2.76 & 6 & Searobins Prionotus sp. & 5.09 \\
\hline 7 & Anchovies, Engraulidae & 1.01 & 7 & Hakes Urophycis spp. & 4.77 \\
\hline 8 & & $<1.00$ & 8 & Mackerel Auxis sp. & 4.37 \\
\hline$\downarrow$ & & $\downarrow$ & 9 & Fourspot flounder Hippoglossina oblonga & 3.87 \\
\hline \multirow[t]{7}{*}{93} & & & 10 & Cusk eels, Ophididae & 3.46 \\
\hline & & & 11 & Black sea bass Centropristis striata & 2.77 \\
\hline & & & 12 & Silver anchovy Engraulis eurystole & 1.36 \\
\hline & & & 13 & Flounders, Bothidae & 1.19 \\
\hline & & & 14 & Silver hake, Merluccius bilinearis & 1.06 \\
\hline & & & 15 & & $<1.00$ \\
\hline & & & $\begin{array}{c}\downarrow \\
106\end{array}$ & & $\downarrow$ \\
\hline \multicolumn{6}{|c|}{ Autumn } \\
\hline & GULF OF MAINE & & & GEORGES BANK & \\
\hline 1 & Atlantic herring Clupea harengus & 84.06 & 1 & Atlantic herring Clupea harengus & 49.41 \\
\hline 2 & Silver hake Merluccius bilinearis & 5.60 & 2 & Lanternfish Ceratoscopelus maderensis & 11.37 \\
\hline 3 & Fourbeard rockling Enchelyopus cimbrius & 2.60 & 3 & Hakes Urophycis spp. & 8.24 \\
\hline 4 & Hakes Urophycis spp. & 2.14 & 4 & Windowpane Scophthalmus aquosus & 7.93 \\
\hline 5 & Butterfish Peprilus triacanthus & 1.92 & 5 & Silver hake Merluccius bilinearis & 6.24 \\
\hline 6 & Witch flounder Glyptocephalus cynoglossus & 1.63 & 6 & Offshore hake Merluccius albidus & 2.14 \\
\hline 7 & & $<1.00$ & 7 & Gulf Stream flounder Citharichthys arctifrons & 1.50 \\
\hline$\downarrow$ & & $\downarrow$ & 8 & Flounders Bothus sp. & 1.39 \\
\hline \multirow[t]{6}{*}{24} & & & 9 & Barracudinas, Paralepididae & 1.31 \\
\hline & & & 10 & Cusk eels, Ophidiidae & 1.27 \\
\hline & & & 11 & & $<1.00$ \\
\hline & & & $\downarrow$ & & $\downarrow$ \\
\hline & & & 69 & & \\
\hline & SOUTHERN NEW ENGLAND & & & MID-ATLANTIC BIGHT & \\
\hline 1 & Hakes Urophycis spp. & 43.70 & 1 & Searobins Prionotus spp. & 26.29 \\
\hline 2 & Silver hake Merluccius bilinearis & 14.97 & 2 & Atlantic croaker Micropogonias undulatus & 14.34 \\
\hline 3 & Gulf Stream flounder Citharichthys arctifrons & 8.10 & 3 & Hakes Urophycis spp. & 13.97 \\
\hline 4 & Lanternfish Ceratoscopelus maderensis & 6.93 & 4 & Gulf Stream flounder Citharichthys arctifrons & 9.50 \\
\hline 5 & Summer flounder Paralichthys dentatus & 4.86 & 5 & Smallmouth flounder Etropus microstomus & 9.41 \\
\hline 6 & Windowpane Scophthalmus aquosus & 4.82 & 6 & Flounders, Bothidae & 4.53 \\
\hline 7 & Cusk eels, Ophidiidae & 3.04 & 7 & Cusk eels, Ophidiidae & 4.06 \\
\hline 8 & Flounders, Bothidae & 1.70 & 8 & Windowpane Scophthalmus aquosus & 3.12 \\
\hline 9 & Offshore hake Merluccius albidus & 1.47 & 9 & Summer flounder Paralichthys dentatus & 1.62 \\
\hline 10 & Barracudinas, Paralepididae & 1.24 & 10 & Anchovies, Engraulidae & 1.57 \\
\hline 11 & Flounders Bothus sp. & 1.17 & 11 & Fourspot flounder Hippoglossina oblonga & 1.40 \\
\hline 12 & & $<1.00$ & 12 & Weakfish Cynoscion regalis & 1.30 \\
\hline$\downarrow$ & & $\downarrow$ & 13 & Silver anchovy Engraulis eurystole & 1.25 \\
\hline \multirow[t]{3}{*}{79} & & & 14 & & $<1.00$ \\
\hline & & & $\downarrow$ & & $\downarrow$ \\
\hline & & & 84 & & \\
\hline
\end{tabular}

frons, and anchovy (Engraulidae) are the most abundant species (Table 2).

In autumn the number of species decline, ranging from 24 in the Gulf of Maine to 84 in the Mid-Atlantic Bight. Atlantic herring Clupea harengus is the dominant larvae in the Gulf of Maine. Herring larvae and lanternfish rank high in percentage composition on
Georges Bank but the abundance levels for all larvae are low in autumn. Both the silver hake and other hakes are predominant in Southern New England. Further south, in the Mid-Atlantic Bight, the predominant species are searobins Prionotus sp., Atlantic croaker Micropogonias undulatus, and hakes (Table 2). 


\section{Spawning patterns}

The spawning patterns of 11 of the more important species selected on the basis of abundance and their actual or potential importance as a resource are classified based on gradients of larval densities. Atlantic herring were abundant in the early 1970's, but because of the decline in abundance during the late 1970's and early 1980's on Georges Bank (Fig. 5), they have been omitted from our analyses.

Redfish, cod, and haddock are most abundant within Georges Bank and the Gulf of Maine; they are classified as gyre species. Redfish are predominant in the deeper waters of the Gulf of Maine, haddock and cod larvae are in high densities on Georges Bank, and on the shoals of the Scotian Shelf (Fig. 6). Bluefish Pomatomus saltatrix, searobins, and anchovy are the most abundant larvae over the gently sloping plain in the southern half of the survey area. Bluefish and searobins are classified as shelf-plain species. In the Mid-Atlantic Bight bluefish undergo peak spawning during late June. Larvae in this area are produced by the northern spawning stock of bluefish (Kendall and Walford, 1979). Anchovy are more abundant in the inner half of the shelf plain, and spawn from the

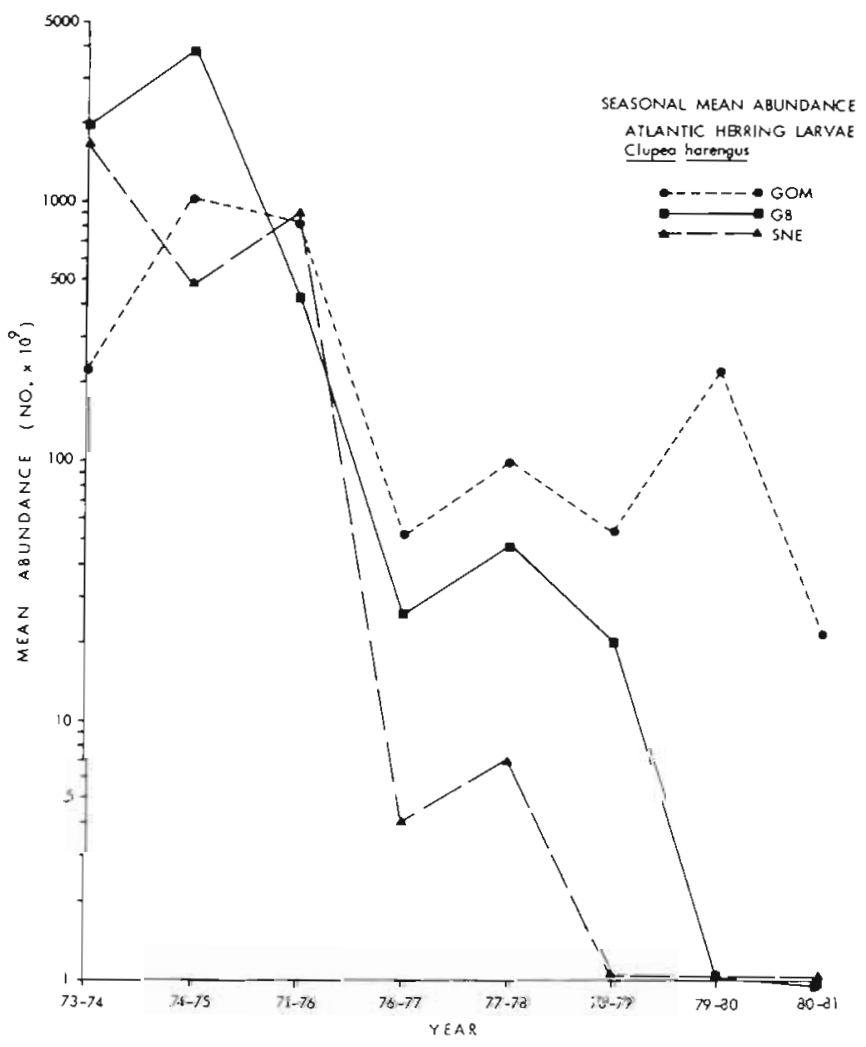

Fig. 5. Decline in abundance of Atlantic herring larvae, Gulf of Maine (GOM), Georges Bank (GB), and Southern New England (SNE), based on changes in mean seasonal abundance $\left(\right.$ No.'s $\left.\times 10^{9}\right)$ in each of the subareas, 1973-1981 seaward ends of the estuaries to the inner margin of the shelf. Anchovy are therefore classified as shelfestuarine species (Fig. 7).

Two important pelagic species, Atlantic mackerel and Atlantic menhaden Brevoortia tyrannus, spawn during their seasonal migrations (Sette, 1950; Reintjes, 1969; Berrien, 1978). The spatial gradient of Atlantic menhaden larvae is greatest in autumn in the MidAtlantic Bight. In contrast, Atlantic mackerel egg densities increase northward in spring. Because of their spawning patterns both species are grouped as shelf-migrants (Fig. 8).

The spawning stocks of silver hake, other hakes, and sand eel are ubiquitous, extending over the entire shelf with substantial numbers of larvae in each of the 4 subareas (Fig. 9).

The mean concentrations of larvae in each of the subareas, for the 1977-80 MARMAP time-series lend support to the designation of spawning patterns of the shelf-shoal gyre, shelf-deep gyre, shelf estuarine, shelf-plain, shelf-migrants, and shelf ubiquitous species. Larvae of cod and haddock are concentrated on Georges Bank within the relatively shoal gyre system, whereas redfish are concentrated within the deep water gyre system of the Gulf of Maine. Concentrations of anchovy larvae are limited to the Mid-Atlantic Bight and the dominant influence of the estuaries of the area. Both bluefish and searobin are found in maximum concentrations over the entire shelf-plain of the MidAtlantic Bight. Although Atlantic mackerel and Atlantic menhaden populations are at low levels, their larvae are present in relatively significant numbers in two subareas, the Mid-Atlantic Bight and Southern New England, reflecting the interareal movement of spawning adults. The larvae of the ubiquitous species - sand eel, silver hake, and other hakes - are found in significant concentrations in each of the 4 subareas: Gulf of Maine, Georges Bank, Southern New England, and Mid-Atlantic Bight (Table 3).

\section{Ichthyoplankton, primary production, and zooplank- ton linkage}

Mean primary production values of $330 \mathrm{~g} \mathrm{C} \mathrm{m}^{-2} \mathrm{yr}^{-1}$ exceed those for areas producing similar groups of mixed demersal and pelagic species including the North Sea (100 $\mathrm{g} \mathrm{C} \mathrm{m}^{-2} \mathrm{yr}^{-1}$; Steele, 1974), and the Scotian Shelf (102 $\mathrm{g} \mathrm{C} \mathrm{m}^{-2} \mathrm{Yr}^{-1}$; Mills and Fournier, 1979). Primary production based on measurements made during the MARMAP surveys is sustained at about $1 \mathrm{~g} \mathrm{C} \mathrm{m}^{-2} \mathrm{~d}^{-1}$ in each of the subareas through most of the year except for the winter low (Dec-Jan); daily rates exceeding $2 \mathrm{~g} \mathrm{C} \mathrm{m}^{-2} \mathrm{~d}^{-1}$ occur during spring and autumn blooms (O'Reilly and Busch, 1983). 

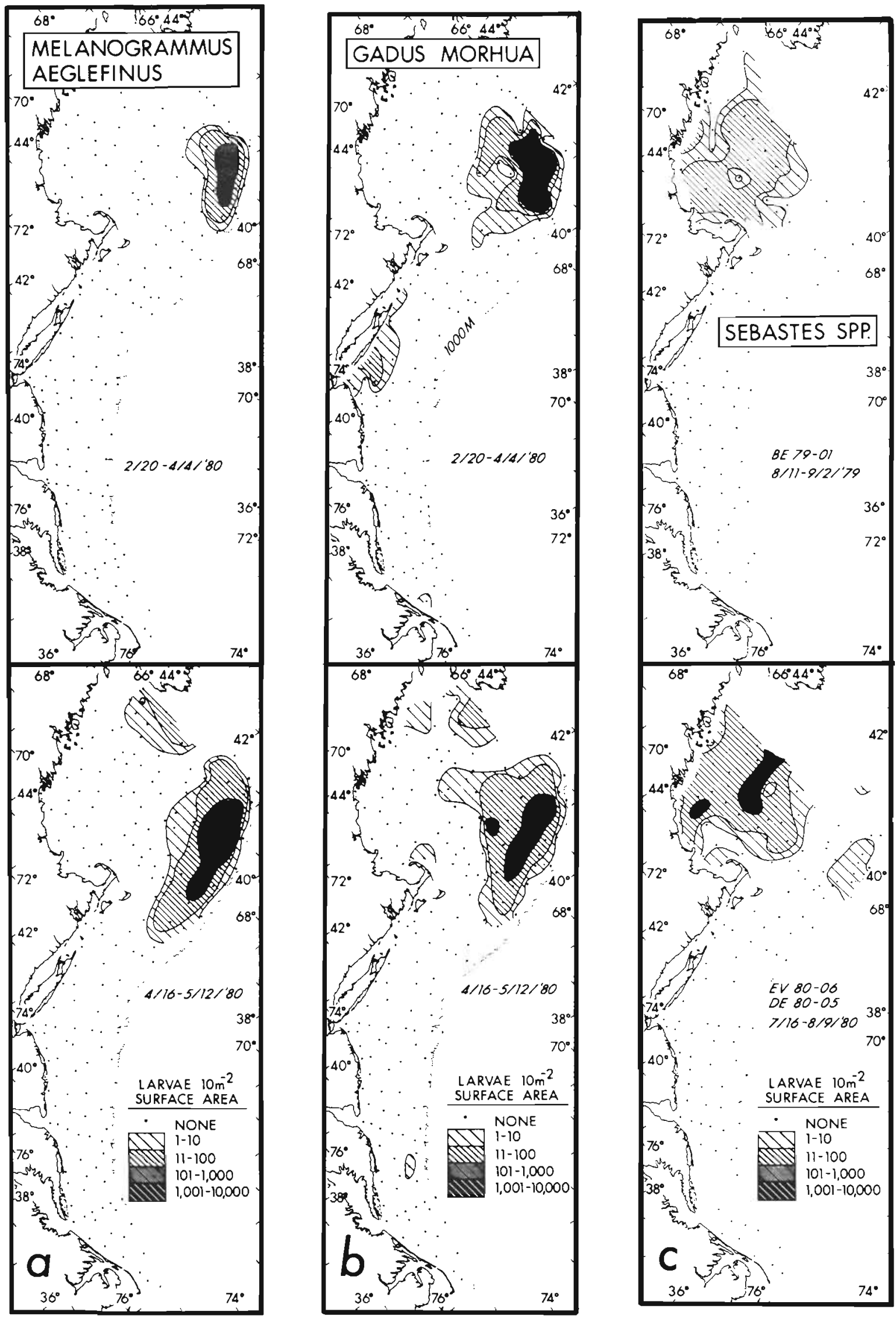

Fig. 6. Distribution and abundance patterns of larvae of shelf-gyre fish spawners based on MARMAP ichthyoplankton collections. Haddock (a), cod (b), redfish (c) 

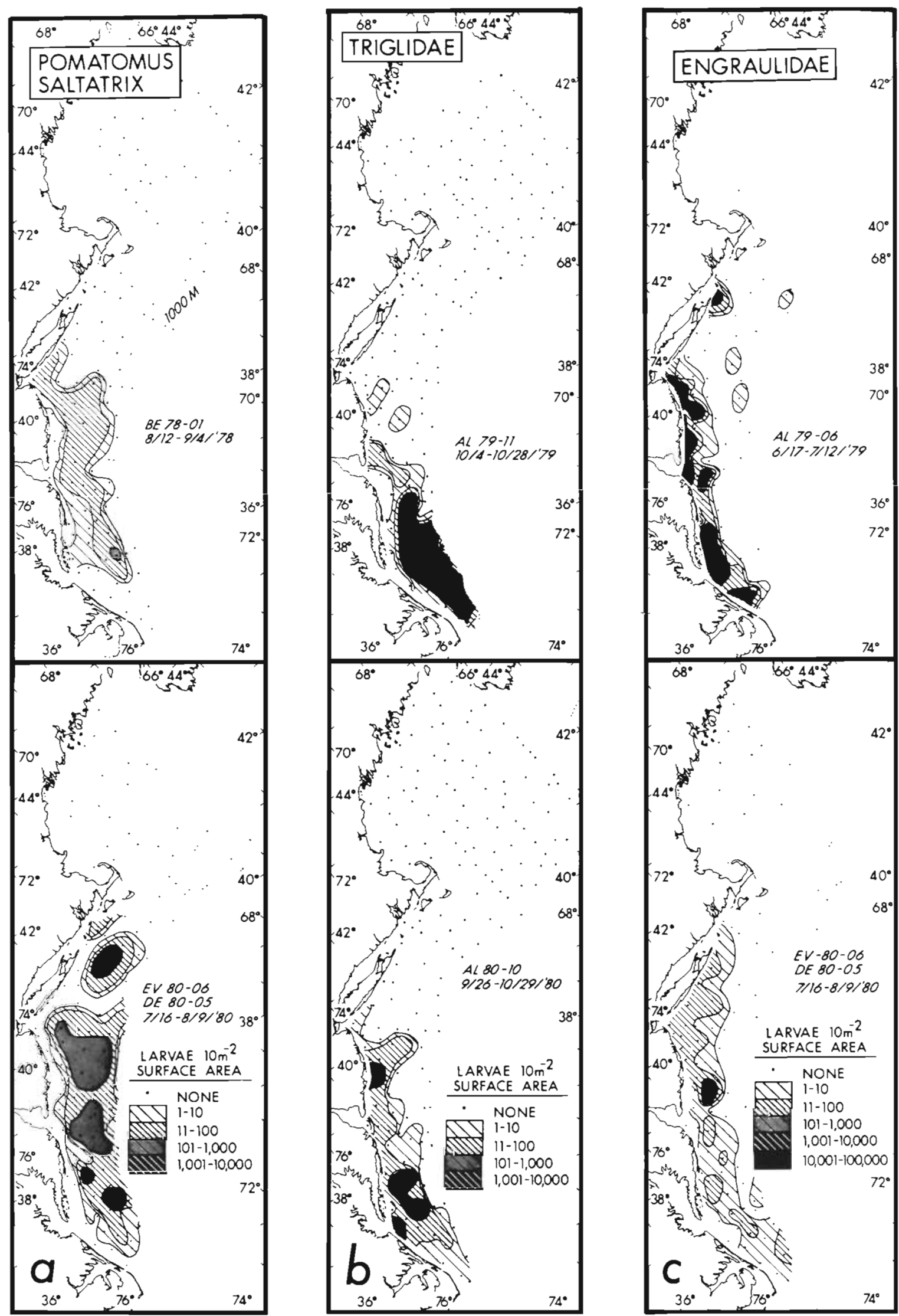

Fig. 7. Distribution and abundance patterns of larvae belonging to 2 shelf-plain spawners based on MARMAP ichthyoplankton surveys - bluefish (a) and searobins (b). Distribution and abundance patterns of larvae whose adults have been classified as belonging to shelf-estuarine spawners based on MARMAP ichthyoplankton surveys - anchovy (c) 



Fig. 8. Distribution and abundance patterns of ichthyoplankton whose adults have been classified as shelf-migrant spawners Atlantic mackerel eggs (a) depicting movement of adults northward in spring, and Atlantic menhaden larvae (b) depicting movement southward in late autumn. (Adapted from Berrien et al., 1981, and Kendall and Reintjes, 1975) 

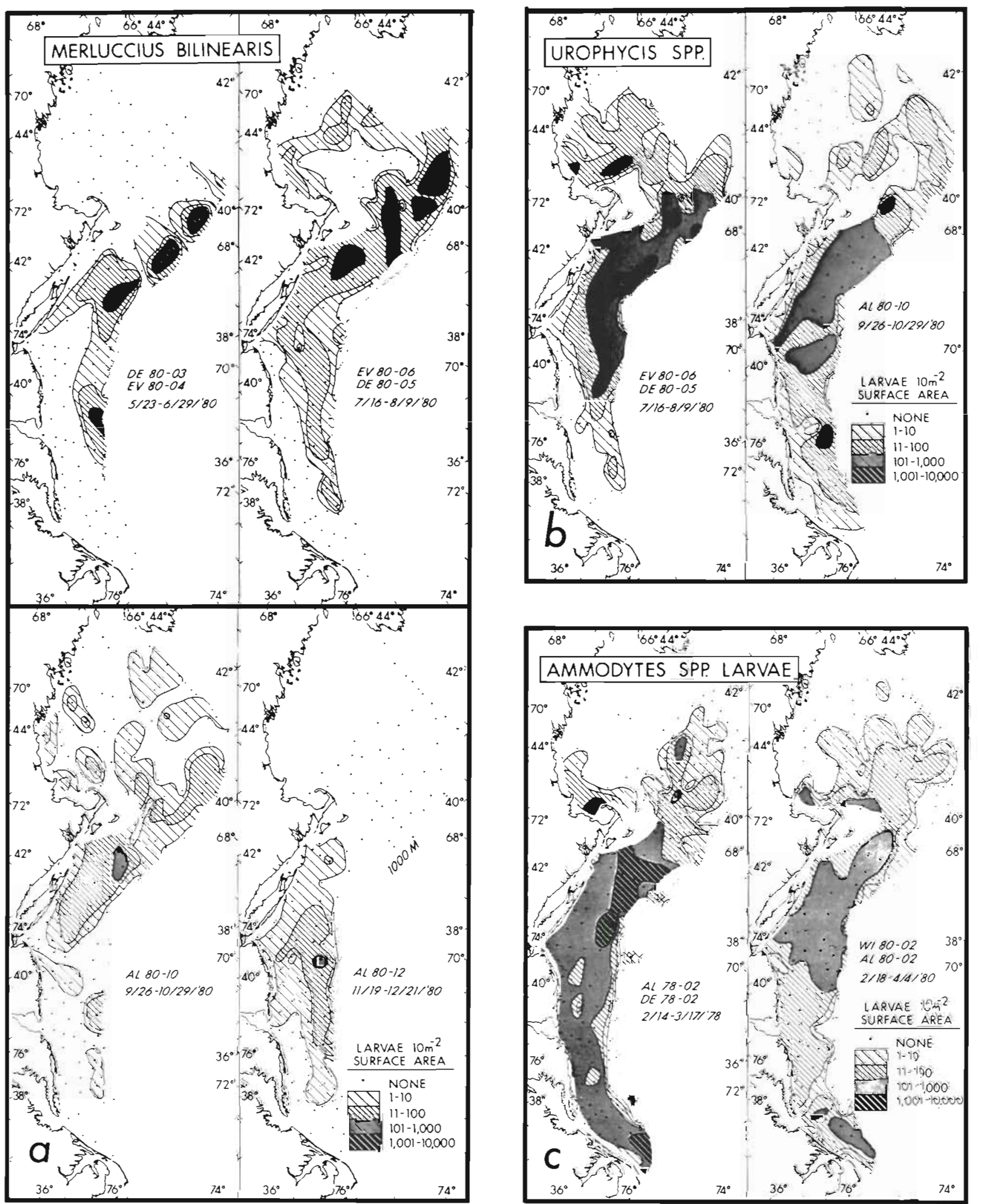

Fig. 9. Distribution and abundance patterns of larvae whose adults are classified as ubiquitous spawners based on MARMAP surveys - silver hake (a), other hakes (b), sand eel (c) 
Table 3. Mean concentrations of larvae $\times 10^{\mathrm{n}}$ classified according to spawning patterns among each of four subareas of the northeast continental shelf - Gulf of Maine, Georges Bank, Southern New England, and the Mid-Atlantic Bight. Area key see legend to Fig, 1

\begin{tabular}{|c|c|c|c|c|}
\hline & \multirow[t]{2}{*}{ Area } & \multicolumn{3}{|c|}{$\bar{x}$ Density $1977-80$} \\
\hline & & high & moderate & low \\
\hline \multicolumn{5}{|c|}{ Shelf-shoal gyre } \\
\hline \multirow[t]{4}{*}{ Haddock } & GOM & - & $37 \times 10^{9}$ & - \\
\hline & $\mathrm{GB}$ & $539 \times 10^{9}$ & - & - \\
\hline & $\mathrm{SNE}$ & - & $28 \times 10^{9}$ & - \\
\hline & MAB & - & - & - \\
\hline \multirow[t]{4}{*}{ Cod } & GOM & - & $13 \times 10^{9}$ & - \\
\hline & $\mathrm{GB}$ & $181 \times 10^{9}$ & - & - \\
\hline & SNE & - & - & $7 \times 10^{9}$ \\
\hline & $\mathrm{MAB}$ & - & - & $160 \times 10^{6}$ \\
\hline \multicolumn{5}{|c|}{ Shelf-deep gyre } \\
\hline \multirow[t]{4}{*}{ Redfish } & GOM & $325 \times 10^{9}$ & - & - \\
\hline & $\mathrm{GB}$ & - & - & $5 \times 10^{9}$ \\
\hline & SNE & - & - & $265 \times 10^{6}$ \\
\hline & $\mathrm{MAB}$ & - & - & - \\
\hline \multicolumn{5}{|l|}{ Shelf-estuarine } \\
\hline \multirow[t]{4}{*}{ Anchovy } & GOM & - & - & - \\
\hline & $\mathrm{GB}$ & - & - & - \\
\hline & SNE & - & $41 \times 10^{9}$ & - \\
\hline & MAB & $231 \times 10^{9}$ & - & - \\
\hline \multicolumn{5}{|l|}{ Shelf-plain } \\
\hline \multirow[t]{4}{*}{ Bluefish } & GOM & - & - & - \\
\hline & GB & - & - & - \\
\hline & SNE & - & $34 \times 10^{9}$ & - \\
\hline & $\mathrm{MAB}$ & $158 \times 10^{9}$ & - & - \\
\hline \multirow[t]{4}{*}{ Searobin } & GOM & - & - & - \\
\hline & $\mathrm{GB}$ & - & - & - \\
\hline & SNE & - & - & $2 \times 10^{9}$ \\
\hline & $\mathrm{MAB}$ & $280 \times 10^{9}$ & - & - \\
\hline \multicolumn{5}{|l|}{ Shelf-migrants } \\
\hline \multirow[t]{4}{*}{ Mackerel } & GOM & - & - & $2 \times 10^{9}$ \\
\hline & $\mathrm{GB}$ & - & - & $946 \times 10^{6}$ \\
\hline & SNE & - & $70 \times 10^{9}$ & - \\
\hline & MAB & - & $32 \times 10^{9}$ & - \\
\hline \multirow[t]{4}{*}{ Menhaden } & GOM & - & - & - \\
\hline & $\mathrm{GB}$ & - & - & - \\
\hline & SNE & - & - & $88 \times 10^{6}$ \\
\hline & $\mathrm{MAB}$ & - & - & $103 \times 10^{6}$ \\
\hline \multicolumn{5}{|c|}{ Shelf-ubiquitous } \\
\hline \multirow[t]{4}{*}{ Silver hake } & GOM & - & $34 \times 10^{9}$ & - \\
\hline & $\mathrm{GB}$ & $542 \times 10^{9}$ & - & - \\
\hline & SNE & $251 \times 10^{9}$ & - & - \\
\hline & $\mathrm{MAB}$ & - & $20 \times 10^{9}$ & - \\
\hline \multirow[t]{4}{*}{ Hake spp. } & GOM & $95 \times 10^{9}$ & - & - \\
\hline & GB & $431 \times 10^{9}$ & - & - \\
\hline & SNE & $835 \times 10^{9}$ & - & - \\
\hline & $\mathrm{MAB}$ & $62 \times 10^{9}$ & - & - \\
\hline \multirow[t]{4}{*}{ Sand eel } & GOM & $153 \times 10^{9}$ & - & - \\
\hline & GB & $230 \times 10^{9}$ & - & - \\
\hline & SNE & $3138 \times 10^{9}$ & - & - \\
\hline & $\mathrm{MAB}$ & $1368 \times 10^{9}$ & - & - \\
\hline
\end{tabular}

Recent grazing studies suggest that the dominant copepods - Calanus finmarchicus, Pseudocalanus minutus, and Centropages typicus - on the northeastern shelf are not food limited (Dagg and Grill, 1980; Dagg and Turner, 1982). Only about $50 \%$ of the annual particulate primary production of the northeastern 
shelf is grazed by the copepod community (Walsh, 1981; Cohen et al., 1982a; Dagg and Turner, 1982). The high levels of primary production appear to be adequate for sustaining the cohort production of $C$. finmarchicus, $P$. minutus, and $C$. typicus in each of the subareas.

In cases where ichthyoplankton production is linked to increases in zooplankton biomass, some apparent temporal displacement between zoo- and ichthyoplankton is expected since the nets used $(0.333 \mathrm{~mm})$ do not efficiently retain the juvenile forms of the dominant copepods. Zooplankton production can be pre-

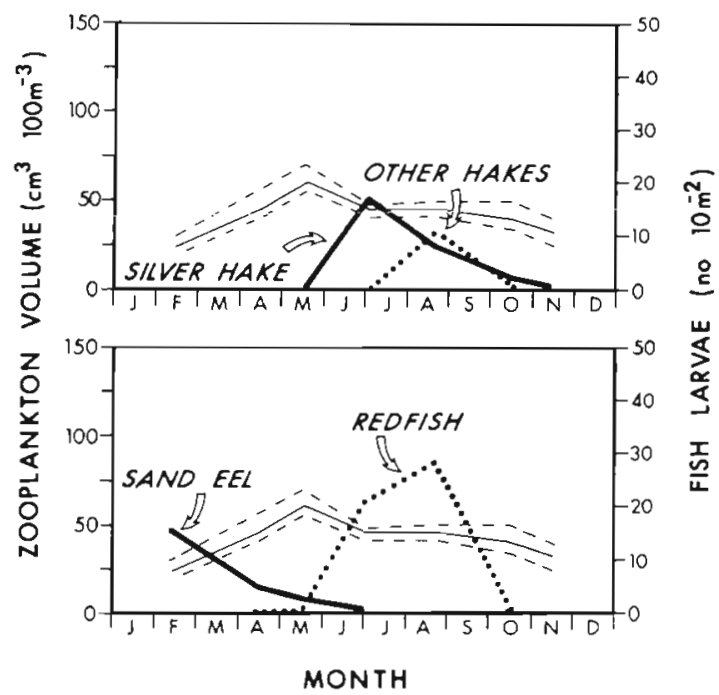

Fig. 10. Gulf of Maine, 1977-80. Seasonal abundance patterns of fish larvae of dominant species. Unlabeled line: mean seasonal zooplankton biomass, plotted with confidence intervals of \pm 1 standard error

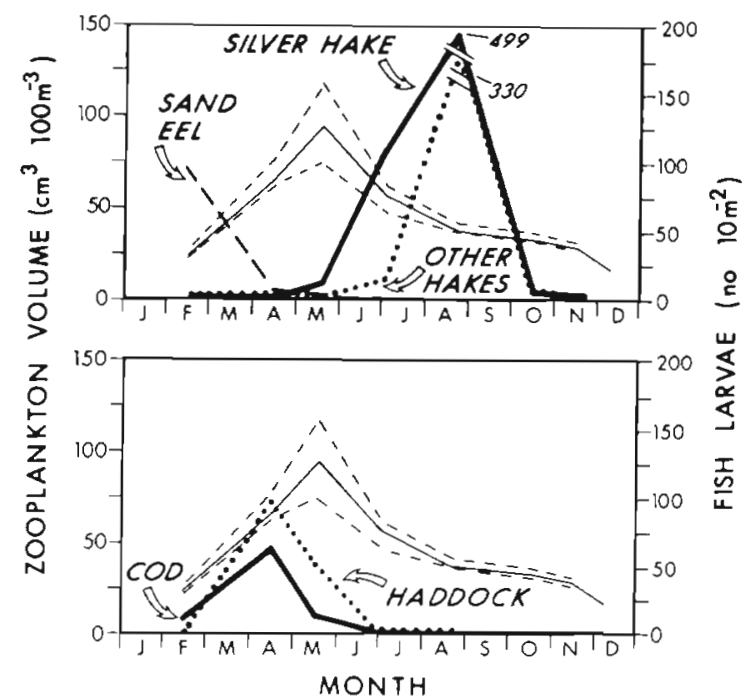

Fig. 11. Georges Bank, 1977-80. Seasonal abundance patterns of fish larvae of dominant species. Unlabeled line: mean seasonal zooplankton biomass, plotted with confidence intervals of \pm 1 standard error sumed to increase 1 to $2 \mathrm{wk}$ before a rise in abundance is apparent in our figures.

In the Gulf of Maine the production of redfish larvae $(1977-80)$ follows the spring increase in zooplankton abundance and is maintained during the summer period of cohort production of their zooplankton prey (Fig. 10). The dominant zooplankton in the subarea is Calanus finmarchicus (Sherman et al., 1983) which is an important prey species of redfish (Bainbridge and McKay, 1968; Marak, 1974). Silver hake and other hakes peak within the prolonged spring through autumn production of copepods, the principal prey of gadoid larvae (Last, 1978; Sumida and Moser, 1980).

On Georges Bank, cod and haddock larval production is in synchrony with the spring zooplankton peak (Fig. 11) dominated by Calanus finmarchicus and Pseudocalanus minutus (Sherman et al., 1983), 2 important prey of these gadoids (Marak, 1960; Sherman et al., 1981b). The larvae of silver hake and other hakes are out of synchrony with the maximal zooplankton abundance. However, they do occur in increasing numbers during the late summer swarming of Centropages typicus (Sherman et al., 1983). In Southern New England, Atlantic mackerel larvae are in synchrony with the ascending limb of the spring zooplankton curve. This contrasts to the hakes which peak in larval abundance in late summer during a period of almost constant zooplankton abundance (Fig. 12). Atlantic menhaden larvae increase in abundance from Southern New England to the Mid-Atlantic Bight (Judy and Lewis, 1983) coincident with the autumn maximum in zooplankton abundance. Other species in the Mid-Atlantic Bight - including anchovy, bluefish,

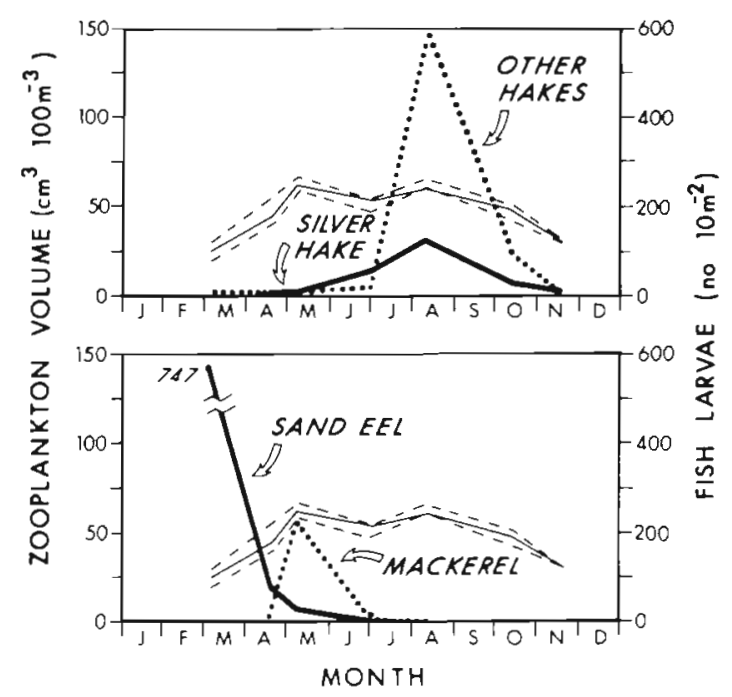

Fig. 12. Southern New England waters, 1977--80. Seasonal abundance patterns of fish larvae of dominant species. Unlabeled line: mean seasonal zooplankton biomass, plotted with confidence intervals of \pm 1 standard error 
and searobin - peak in abundance under the steadily ascending limb of zooplankton abundance from June through October (Fig. 13).

Correspondence between zooplankton production and peak larval abundance does not hold for the ubiquitous species. Only in the case of silver and other hakes in the Southern New England region is synchrony found. The ubiquitous species, silver hake, other hakes, and sand eel spawn over an extended period of time (Colton et al., 1979). Sand eel eggs are produced through the winter months. The eggs of silver hake are common April to November in each of the subareas (Fig. 14), as are the eggs of other hakes. In contrast, haddock complete their spawning in the Georges Bank area in a 30 to $60 \mathrm{~d}$ period (Bigelow and Schroeder, 1953). Maximum abundance of larvae of the ubiquitous species does not represent a peak in spawning but rather, is a reflection of optimal conditions for larval survival and growth. This can be seen in the Gulf of Maine, where silver hake spawns from late May to late October, with a peak around the first week in September (Fig. 14). Despite this spawning pattern, silver hake larvae reach maximum abundance in the Gulf of Maine in early July (Fig, 10), coincident with increasing abundance of Centropages typicus, an important prey of this species.

Larvae of sand eel are distributed over a wide area of the shelf during the winter low in biological production (Sherman et al., 1981a). Their large hatch size and ability to maintain themselves without food for up to $20 \mathrm{~d}$ (Smigielski et al., 1984) allow them to exploit the early spring zooplankton bloom on Georges Bank before the larval haddock and cod are of a size to compete.

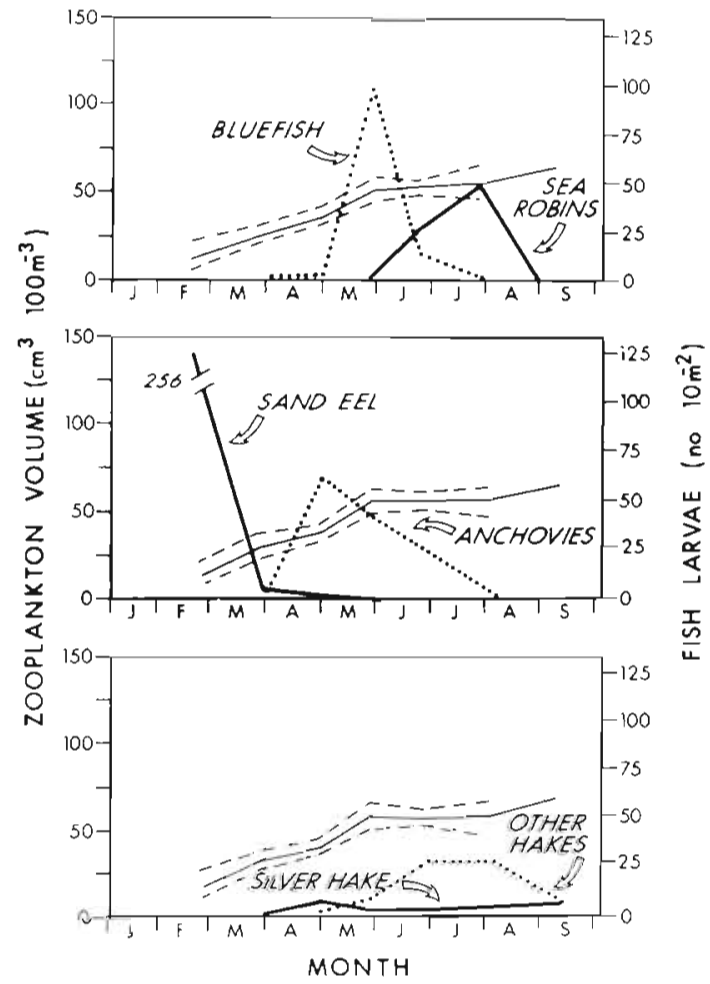

Fig. 13. Mid-Atlantic Bight, 1977-80. Seasonal abundance patterns of fish larvae of dominant species. Unlabeled line: mean seasonal zooplankton biomass, plotted with confidence intervals of \pm 1 standard error

\section{DISCUSSION}

\section{Ecological implications of larval distributions}

The demersal and pelagic species constituting the finfish biomass of the shelf appear to have evolved
Fig. 14. Estimated daily silver hake egg production in 4 subareas and in total survey area, 1979. (From Berrien, 1983)

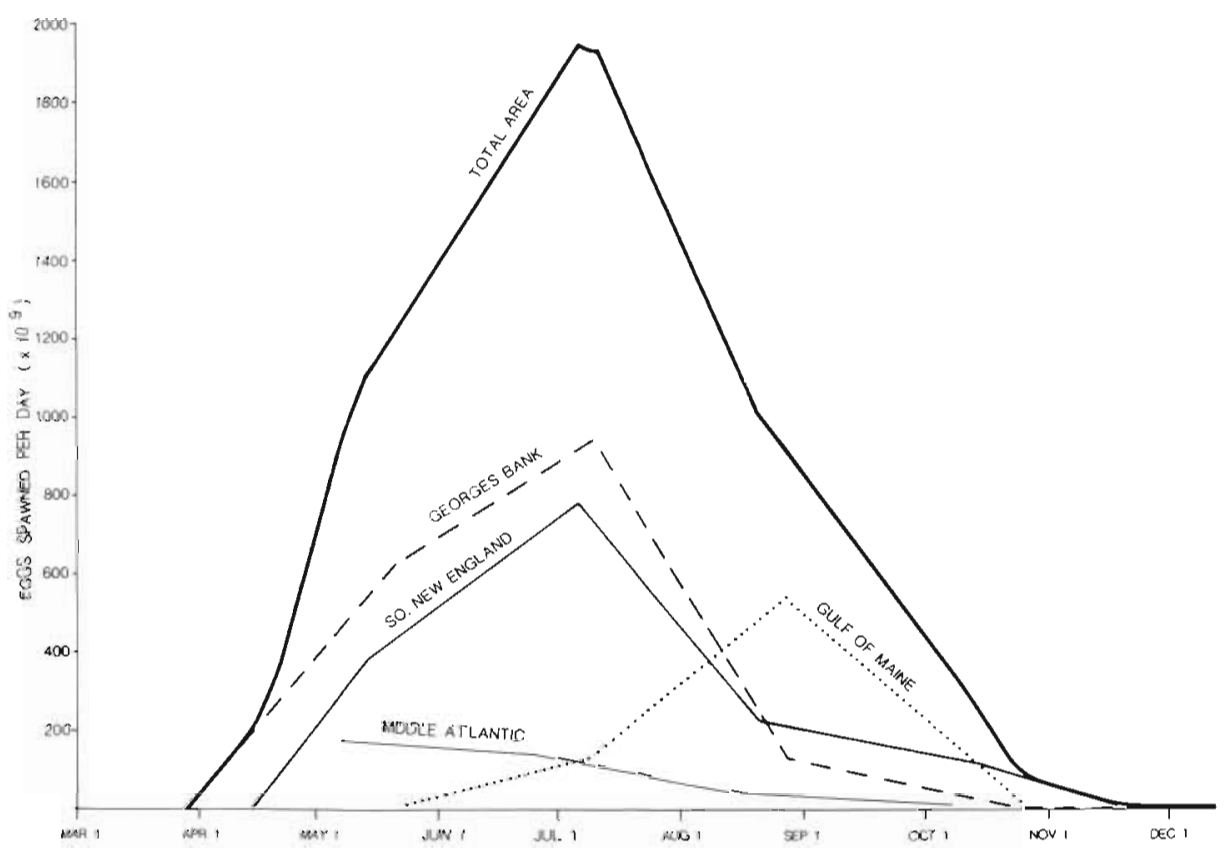


spawning patterns that reflect successful ecological adaptation. The competitive advantages of spawning patterns are discussed for each of the species:

Haddock - shelf-shoal gyre, spring spawner. Among the advantages of spring spawning within the Georges Bank gyre are: (1) synchrony of larval production with spring zooplankton increase; (2) gyre development enhances retention of larvae in areas of high preydensity and decreases the probability for advection to areas of low food availability maintaining the larvae in the southernmost major spawning area for haddock in the Northwest Atlantic. Although advection has been hypothesized as a principal source of larval haddock mortality (Walford, 1938), no evidence of large-scale advection of shelf-gyre species off Georges Bank has been demonstrated (Colton and Byron, 1977; Cohen et al., 1982b; Laurence and Burns, 1982). Among the disadvantages of gyre spawning are: (1) the larval period is relatively short for linking spawning to prey availability, increasing the probability of mismatch with an optimal prey field; (2) the limited areal distribution of spawning increases vulnerability to $\mathrm{co}-$ habiting predators.

Cod - shelf-shoal gyre, spring spawner. As with haddock, cod larvae are concentrated on Georges Bank and their production cycle is in synchrony with the zooplankton peak within the gyre. However, the areal distribution of larvae is greater than that for haddock within and outside of the Georges Bank gyre, increasing the probability of survival from (1) predation, and (2) years of low zooplankton production within the gyre. Recent information based on laboratory and field observation suggests that early cod larvae are more successful predators than haddock (Laurence et al., 1981; Kane, 1984). Also, their tolerance to higher temperatures increases the probability for survival on the shoals west of Georges Bank. The lower recruitment variability of cod when compared to haddock (Hennemuth et al., 1980; Clark et al., 1982; Serchuk et al., 1982) is likely related to the wider distribution outside of the Georges Bank gyre, reducing vulnerability of the spawning stocks to fishing mortality.

Redfish - shelf-deep gyre, summer spawner. The ovoviviparous redfish produce larvae within the Gulf of Maine gyre in a temporal and spatial pattern that is coincident with the extended period of copepod abundance in summer, following the spring pulse in cohort production.

Anchovy - shelf-estuarine, summer spawner. Larval abundance of anchovy is in synchrony with the increase in zooplankton production. The extensive distribution over the inner half of the continental shelf in the Mid-Atlantic Bight reduces the probability of large scale losses of larvae from natural environmental perturbations.
Bluefish - shelf-plain, summer spawner. In both Southern New England and the Mid-Atlantic Bight, peak abundance of larval bluefish is coincident with zooplankton production. Wide distribution of larvae over the shelf reduces vulnerability to the predator field and environmental perturbation.

Searobin - shelf-plain, autumn spawner. The peak abundance of searobin larvae is coincident with the mean annual autumn peak in zooplankton abundance in the Mid-Atlantic Bight. Wide shelf distribution reduces vulnerability from environmental perturbation.

Atlantic mackerel - shelf migrant, spring-summer spawner. Based on the distribution of eggs and larvae, Atlantic mackerel migrate offshore in winter and along the shelf from spring through autumn (Sette, 1950). This migration strategy enhances survival by keeping larvae in high density zooplankton prey fields; however, the impact of fishing mortality has reduced the size of the spawning stock off the northeastern US coast (Anderson, 1982).

Atlantic menhaden - shelf migrant, autumn spawner. Atlantic menhaden migrate offshore to spawn and from north to south along the shelf in autumn for feeding during a period of maximal zooplankton abundance in the Mid-Atlantic Bight. An intensive fishing effort on the northeast shelf has significantly reduced spawning stock size (Schaaf and Huntsman, 1972; Schaaf, 1979).

Silver hake, other hakes - shelf ubiquitous, extended spawners. The extended spawning period and broad distribution of larvae over the shelf from the Gulf of Maine to Cape Hatteras maximizes the probability of prey-encounter. The hakes peak later than the other important species (sand eel, Atlantic mackerel, and lanternfish in Southern New England; cod and haddock on Georges Bank) during a period when Centropages typicus, a small calanoid copepod, known as an important prey species of hake is abundant. Although spawning in open water near the shelf-slope increases the probability for advective losses of larvae, the relatively high density of larvae ( $\overline{\mathrm{X}} 4 \mathrm{yr}$ peak abundance of $>2,500 \times 10^{9}$ ) enhances survival. The wide distribution of larvae over the shelf decreases the probability of large-scale mortalities from environmental perturbation.

Sand eel - shelf ubiquitous, late-winter spawner. Larvae of the sand eel are distributed over a wide area of the shelf during the annual low in biological production. However, they are the only dominant larvae during late winter and are not in competition with other members of the ichthyoplankton community for zooplankton prey. When larvae hatch, they are relatively large and can search a wider prey field than smaller larvae. Based on laboratory observations, they can 
maintain themselves in a viable state without food for up to $20 \mathrm{~d}$ (Smigielski et al., 1984), which would carry them to the initiation of the spring swarming of their copepod prey. Their enormous abundance over the shelf $\left(\overrightarrow{\mathrm{X}} 4 \mathrm{yr}\right.$ peak abundance $5,383 \times 10^{9}$ ) compensates for any significant losses to advective processes or short-term environmental perturbation. Sand eel is an opportunistic species undergoing a population explosion resulting from significant reduction in the biomass of cohabiting predatory Atlantic mackerel and Atlantic herring populations (Sherman et al., 1981a).

\section{Spawning strategies and competitive advantage}

Our results provide evidence of spawning adaptation in 11 important continental shelf fish species to average biological and oceanographic conditions that lead to enhanced survival. Species classified as ubiquitous spawners - sand eel, silver hake, and other hakes - appear to have developed a competitive advantage over other fish species within the shelf ecosystem in maintaining relatively high abundance levels of eggs and larvae over a wide temporal and geographic range within the shelf ecosystem. This seed stock takes advantage of favorable conditions, developing rapidly when the environment allows. Other species - haddock, cod, redfish, bluefish, anchovy, and searobin - have developed spawning strategies that optimize encountering prey with respect to temporal and spatial increases in zooplankton abundance. Under natural environmental conditions, 2 species, Atlantic mackerel and Atlantic menhaden, have evolved spawning patterns wherein the spawning adults migrate in synchrony with the increasing spring spawning peak (Atlantic mackerel) and autumn peak (Atlantic menhaden) in zooplankton abundance off the northeastern coast.

Distributions of fish larvae in other areas suggest that spawning strategies vary with geographical location. On the Scotian Shelf distributions of larvae of cod, haddock, pollock, and silver hake eggs and larvae have been reported to be associated with gyres that tend to concentrate and maintain them over the relatively shallow banks of the shelf (O'Boyle et al., 1983). The cod and haddock observations are in agreement with our results and the haddock observations agree with the results of other studies in the Northwest Atlantic (Homans and Vladykov, 1954; Marak and Livingstone, 1970; Colton et al., 1979) and Northeast Atlantic (Gordon and de Silva, 1980). Our pollock data are insufficient for comparison, but the silver hake distribution patterns are different than O'Boyle et al. (1983) found on the Scotian Shelf. Whereas silver hake are ubiquitous on the USA northeastern shelf, they appear to be gyre-associated on the Scotian Shelf.
Based on a comparison of differences in cod egg and larval distributions between the Scotian Shelf and Northeast Atlantic, O'Boyle et al. (1983) recognized differences in spawning strategies between the gyreassociated larval cod distributions on the Scotian Shelf and the drift patterns of Arcto-Norwegian cod larvae described by Cushing (1981). They further speculate that the general rule proposed by Harden-Jones (1968) relating larval drifts from a spawning area to a nursery area may need to be modified. ' . . to include the possibility that the spawning ground and the nursery are in the same general area ... Our observations on cod and haddock larval distributions tend to confirm the speculation of O'Boyle et al. (1983).

Redfish Sebastes spp. and American plaice Hippoglossoides platessoides were widely scattered over the Scotian Shelf. The gyre-association of redfish larvae in the Gulf of Maine was not observed on the Scotian. Shelf (O'Boyle et al., 1983). Plaice did not occur in sufficient numbers in the MARMAP survey to examine the relation of larval distributions to spawning strategy. In contrast to our findings, O'Boyle et al. (1983) conclude that peaks in larval fish production did not appear in any consistent synchrony with the peaks of zooplankton over the banks of the Scotian Shelf. They argue that the gyre-associated spawning strategies of cod, haddock, and silver hake contribute to the maintenance of stock integrity.

In an examination of recent changes in fish populations of the Mid-Atlantic Bight, Edwards (1976) suggested that most fish and marine organisms are rstrategists. We conclude that the concept of a continuum from $r$ to $K$ reproductive strategies for fish species as proposed by Pianka (1970) is more applicable to the shelf species we examined. The ovoviviparous redfish and the egg-producing haddock and cod, as gyre species, are on the $\mathrm{K}$ side of the continuum, producing eggs at a time which increases the probability that their larvae will encounter sufficient food for growth and survival. In contrast, the ubiquitous hakes and sand eel are r-strategists, spawning over an extended area during a protracted period to ensure that at least some of their larvae will encounter favorable conditions for growth and survival. The shelfplain species (bluefish, searobin), shelf-estuarine species (anchovy), and shelf migratory (Atlantic mackerel, Atlantic menhaden) represent intermediate reproductive strategies. Among the ubiquitous species, sand eel appears to represent the consummate rstrategist, organisms that are relatively short-lived with short generation times allowing for rapid population expansion under favorable conditions (Miller and Botkin, 1974).

From the observed spatial and temporal trends in ichthyoplankton abundance, we conclude that: (1) 
spawning strategies are adaptations of the spawning biomass to topographic and circulation features of the northeast shelf and the annual plankton production cycle in each of the four subareas - Gulf of Maine, Georges Bank, Southern New England, and the MidAtlantic Bight; (2) gyre, shelf-plain, and shelf-migratory spawners, under average conditions reach peak abundance in synchrony with the seasonal pulses in their zooplankton prey; (3) ubiquitous spawners appear to maintain relatively high densities of eggs over a wide temporal and spatial range within the shelf ecosystem, thereby enabling them to respond rapidly to favorable environmental conditions.

\section{LITERATURE CITED}

Aitchison, J. (1955). On the distribution of a positive random variable having a discrete probability mass at the origin. J. Am. statist. Ass. 50: 272, 901

Anderson, E. D. (1982). Status of the Northwest Atlantic mackerel stock - 1982. NOAA/NMFS, Northeast Fisheries Center, Woods Hole Laboratory Reference Document No. $82-44$

Bainbridge, V., McKay, B. J. (1968). The feeding of cod and redfish larvae. ICNAF Spec. Publ. 7: 187-217

Berrien, P. L. (1978), Eggs and larvae of Scomber scombrus and Scomber japonicus in continental shelf waters between Massachusetts and Florida. Fish. Bull. U.S. 76 (1): 95-115

Berrien, P. (1983). Silver hake, Merluccius bilinearis, egg census and adult population estimate for 1979 in waters off eastern United States. ICES C.M. 1983/G: 46

Berrien, P., Naplin, A., Pennington, M. R. (1981). Atlantic mackerel, Scomber scombrus, egg production and spawning population estimates for 1977 in the Gulf of Maine, Georges Bank, and Middle Atlantic Bight. Rapp. P.-v. Réun. Cons. int. Explor. Mer 178: 279-288

Bigelow, H. B., Schroeder, W. C. (1953). Fishes of the Gulf of Maine. Fish. Bull. U.S. 53 (74): 1-577

Butman, B., Beardsley, R. C., Magnell, B., Frye, D., Vermersch, J. A., Schlitz, R., Limeburner, R., Wright, W. R., Noble, M. A. (1982). Recent observations of the mean circulation on Georges Bank. J. Phys. Oceanogr 12 (6): 569-591

Clark, S. H., Overholtz, W J., Hennemuth, R. C. (1982) Review and assessment of the Georges Bank and Gulf of Maine haddock fishery. J. Northw. Atl. Fish. Sci. 3: 1-28

Cohen, E. B., Grosslein, M. D., Sissenwine, M. P., Steimle, F., Wright, W. R. (1982a). Energy budget of Georges Bank. In: Mercer, M. C. (ed.) Multispecies approaches to fisheries management advice. Can. Spec. Publ. Fish. Aquat. Sci. 59: 95-107

Cohen, E., Mountain, D., Smith, W (1982b). Physical processes and year-class strength of commercial fish stocks on Georges Bank. EOS, Trans. Am. Geophys. Union 63 (45): 956

Colton, J. B. Jr., Byron, R. R. (1977). Gulf of Maine-Georges Bank ichthyoplankton collected on ICNAF larval herring surveys September 1971-February 1975. U.S. Dep. Commer., NOAA Tech. Rep. NMFS Spec. Sci. Rep.-Fish. 717 : $1-35$

Colton, J B. Jr., St. Onge, J. (1974). Distribution of fish eggs and larvae in continental shelf waters, Nova Scotia to Long Island. Ser. Atlas Mar Environ., Am. Geogr. Soc. Folio 23

Colton, J. B. Jr., Smith, W. G., Kendall, A. W., Berrien, P. L., Fahay, M. P. (1979). Principal spawning areas and times of marine fishes, Cape Sable to Cape Hatteras. Fish. Bull. U.S. 76: 911-915

Cushing, D. H. (1981). Fisheries biology: a study in population dynamics, 2nd ed. University of Wisconsin Press, Madison, Wis.

Dagg, M. J., Grill, D. W. (1980). Natural feeding rates of Centropages typicus females in the New York Bight. Limnol. Oceanogr. 25: 597-609

Dagg, M. J., Turner, J. T. (1982). The impact of copepod grazing on the phytoplankton of Georges Bank and the New York Bight. Can. J. Fish. Aquat. Sci. 39: 979-990

Edwards, R. L. (1976). Middle Atlantic fisheries: recent changes in populations and outlook. Am. Soc. Limnol. Oceanogr. Spec. Symp. 2: 302-311

Emery, K. O., Uchupi, E. (1972). Western North Atlantic Ocean topography rocks, structure, water life and sediments. Am. Ass. Petrol. Geol. Mem. 17: 1-532

Evans, C., O'Reilly, J. (in press). A handbook for the measurement of chlorophyll a in netplankton and nannoplankton. BIOMASS Handbook No. 9, SCAR/SCOR/IABO/ACMRR

Gordon, J. D. M., de Silva, S. S. (1980). The fish populations of the west of Scotland Shelf. Part 1. Oceanogr. Mar. Biol. Ann. Rev, 18: 317-366

Graham, J. J. (1982). Production of larval herring, Clupea harengus, along the Maine coast. J. Northw. Atl. Fish. Sci. 3 (1): $63-85$

Grosslein, M. D. (1969). Groundfish survey program of BCF Woods Hole. Commer. Fish. Rev. 31 (8-9): 22-35

Harden-Jones, J. R. (1968). Fish migration. Arnold. London

Hennemuth, R. C., Palmer, J. E., Brown, B. E. (1980). A statistical description of recruitment in eighteen selected fish stocks. J. Northw. Atl. Fish. Sci. 1: 101-111

Homans, R. E. S., Vladykov, V. D. (1954), Relation between feeding and the sexual cycle of the haddock. J. Fish. Res. Bd Can. 11: 535-542

Ingham, M. C., Armstrong, R. S., Chamberlin, J. L., Cook, S. K., Mountain, D. G., Schlitz, R. J., Thomas, J. P., Bisagni, J. J., Paul, J. F., Warsh, C. E. (1982). Summary of the physical oceanographic processes and features pertinent to pollution distribution in the coastal and offshore waters of the northeastern United States, Virginia to Maine. NEMP Oceanogr. Summ. Rep. NEMP-IV-82-C-0004: 1-160

Judy, M. H., Lewis, R. M. (1983). Distribution of eggs and larvae of Atlantic menhaden, Brevoortia tyrannus, along the Atlantic coast of the United States. U.S. Dep. Commer., NOAA Tech. Rep., NMFS Spec. Sci. Rep.-Fish. 774: 1-23

Kane, J. (1984). The feeding habits of co-occurring cod and haddock larvae from Georges Bank. Mar. Ecol. Prog. Ser. 16: $9-20$

Kendall, A. W., Reintjes, J. W (1975). Geographic and hydrographic distribution of Atlantic menhaden eggs and larvae along the Middle Atlantic coast from R/V Dolphin cruises, 1965-66. Fish. Bull. U.S. 73: 317-335

Kendall, A. W. Jr., Walford, L. A. (1979). Sources and distribution of bluefish, Pomotomas saltatrix, larvae and juveniles off the east coast of the United States. Fish. Bull. U.S. 77 : 213-227

Last, J. M. (1978). The food of three species of gadoid larvae in the eastern English Channel and southern North Sea. Mar. Biol. 48: 377-386

Laurence, G. C., Burns, B. R. (1982). Ichthyoplankton in shelf water entrained by warm-core rings. EOS, Trans. Am. 
Geophys. Union 63 (45): 998

Laurence, G. C., Burns, B. R., Halavik, T. A., Smigielski, A. S. (1981). Implications of direct competition between larval cod (Gadus morhua) and haddock (Melanogrammus aeglefinus) in laboratory growth and survival studies at different food densities. Rapp. P.-v. Réun. Cons. int. Explor Mer 178: 304-311

Lough, R. G., Bolz, G. R., Grosslein, M. D., Potter, D. C. (1981). Abundance and survival of sea herring (Clupea harengus L.) larvae in relation to environmental factors, spawning stock size, and recruitment for the Georges Bank area, 1968-1977 seasons. Rapp. P.-v. Réun. Cons. int. Explor. Мer 178: 220-222

Marak, R. R. (1960). Food habits of larval cod, haddock and coalfish in the Gulf of Maine and Georges Bank area. J. Cons. perm. int. Explor. Mer 25: 147-157

Marak, R. R. (1974). Food and feeding of larval redfish in the Gulf of Maine. In: Blaxter, J. H. S. (ed.) The early life history of fish. Springer-Verlag, Berlin, p. 267-275

Marak, R. R., Colton, J. B. Jr. (1961). Distribution of fish eggs and larvae, temperature, and salinity in the Georges Bank-Gulf of Maine area, 1953. NOAA Tech. Rep. NMFS Spec. Sci. Rep.-Fish. 398: 1-61

Marak, R. R., Colton, J. B. Jr., Foster, D. B. (1962a). Distribution of fish eggs and larvae, temperature, and salinity in the Georges Bank-Gulf of Maine area, 1955. U.S. Dep. Commer., NOAA Tech. Rep., NMFS Spec. Sci. Rep.-Fish. 411: $1-68$

Marak, R. R., Colton, J. B. Jr., Foster, D. B., Miller, D. (1962b). Distribution of fish eggs and larvae, temperature, and salinity in the Georges Bank-Gulf of Maine area, 1956. U.S. Dep. Commer., NOAA Tech. Rep., NMFS Spec, Sci. Rep.-Fish. 412: 1-95

Marak, R. R., Livingstone, R. (1970). Spawning dates of Georges Bank haddock. ICNAF Res. Bull. 7. 56-58

Miller, R. S., Botkin, D. B. (1974). Endangered species: models and predictions. Am. Sci. 62: 172-181

Mills, E. L., Fournier, R. O. (1979). Fish production and the marine ecosystems of the Scotian Shelf, Eastern Canada. Mar Biol. 54: 101-108

Morse, W (1982). Spawning stock biomass estimates of sand lance, Ammodytes sp. off northeastern United States determined from MARMAP plankton surveys, 1974-1980. Int. Coun. Explor Sea Demersal Fish Comm. C.M. 1982/ G: 59

O'Boyle, R. N., Sinclair, M., Conover, R. J., Mann, K. H., Kohler, A. C. (1983). Temporal and spatial distribution of ichthyoplankton communities of the Scotian Shelf in relation to biological, hydrological and physiographic features. Rapp. P.-v. Réun. Cons, int. Explor. Mer 183, in press

O'Reilly, J. E., Busch, D. A. (1983). Phytoplankton primary production for the Northwestern Atlantic shelf. Rapp. P.-v. Réun. Cons. int. Explor. Mer 183: 255-268

Obenchain, C. L. (1981). A study of the larval fish community in the New York Bight from July 1974 to June 1976. Rapp. P.-v. Réun. Cons. int. Explor. Mer 178: 217-219

Pennington, M. (1983). Efficient estimators of abundance for fish and plankton surveys. Biometrics 39: 281-286

Pianka, E. R. (1970). On r- and K-selection. Am. Nat. 104: $592-595$

Posgay, A., Marak, R. R. (1980). The MARMAP bongo zooplankton samplers. J. Northw. Atl. Fish. Sci. 1: 91-99

Reintjes, J. W (1969). Synopsis of biological data on the Atlantic menhaden, Brevoortia tyrannus. U.S. Fish Wildl. Serv., Circ. 320: 1-30

Saville, A. (1981). The estimation of spawning stock size from fish egg and larval surveys. Rapp. P.-v. Réun. Cons. int. Explor. Mer 178: 268-278

Saville, A., Schnack, D. (1981). Some thoughts on the current status of studies of fish egg and larval distribution and abundance. Rapp. P.-v. Réun. Cons. int. Explor Mer 178: 153-157

Schaaf, W. E. (1979). An analysis of the dynamic population response of Atlantic menhaden (Brevoortia tyrannus), to an intensive fishery. Rapp. P.-v. Réun. Cons. int. Explor. Mer 177: 243-251

Schaaf, W. E., Huntsman, G. R. (1972). Effects of fishing on the Atlantic menhaden stock: 1955-1969. Trans. Am. Fish. Soc. 101 (2): 290-297

Serchuk, F. M., Rak, R. S., Penttila, J. (1982). Status of the Georges Bank and Gulf of Maine Atlantic cod stocks, 1982. NOAA/NMFS, NEFC Woods Hole Laboratory Ref. Doc. $82-33$

Sette, O. E. (1950). Biology of the Atlantic mackerel (Scomber scombrus) of North America. Part 2. Migrations and habits. U.S. Fish Wildl. Serv., Fish. Bull. 49: 251-358

Sherman, K. (1980). MARMAP, a fisheries ecosystem study in the NW Atlantic: Fluctuations in ichthyoplankton-zooplankton components and their potential for impact on the system. In: Diemer, F. P., Vernberg, F. J., Mirkes, D. Z. (ed.) Advanced concepts on ocean measurements for marine biology. Belle W. Baruch Institute for Marine Biology and Coastal Research. University of South Carolina Press, Columbia, S. C.

Sherman, K., Green, J. R., Goulet, J. R., Ejsymont, L. (1983). Zooplankton coherence in a large Northwest-Atlantic ecosystem. Fish. Bull. U.S. 81 (4), in press

Sherman, K., Jones, C., Sullivan, L., Smith, W., Berrien, P., Ejsymont, L. (1981a). Congruent shifts in sand eel abundance in western and eastern North Atlantic ecosystems. Nature, Lond. 291: 486-489

Sherman, K., Maurer, R., Byron, R., Green, J. (1981b). Relationship between larval fish communities and zooplankton prey species in an offshore spawning ground. Rapp. P.v. Réun. Cons int. Explor. Mer 178: 289-294

Smigielski, A. S., Halavik, T. A., Buckley, L. J., Drew, S. M., Laurence, G. C. (1984). Spawning, embryo development and growth of the American sand lance Ammodytes americanus in the laboratory. Mar Ecol. Prog. Ser 14: $287-292$

Smith, P. E., Richardson, S. (1977). Standard techniques for pelagic fish egg and larval surveys. FAO Fish. Tech. Pap. 175: $1-100$

Smith, W. G., Sibunka, J. D., Wells, A. (1975). Seasonal distributions of larval flatfishes (Pleuronectiformes) on the continental shelf between Cape Cod, Massachusetts, and Cape Lookout, North Carolina, 1965-66. NOAA Tech. Rep. Spec. Sci. Rep. Fish. 691: 1-68

Steele, J. H. (1974). The structure of marine ecosystems. Harvard University Press, Cambridge, Mass.

Sumida, B. Y., Moser, H. G. (1980). Food and feeding of Pacific hake larvae, Merluccius productus, off southern California and Baja California. CalCOFI Rep. 21 : 161-166

Townsend, D. W. (1984). Comparison of inshore zooplankton and ichthyoplankton populations of the Gulf of Maine. Mar. Ecol. Prog. Ser. 15: 79-90

Walford, L. A. (1938). Effects of currents on the distribution and survival of eggs and larvae of haddock (Melanogrammus aeglefinus) on Georges Bank. Bull. U.S. Bur. Fish 29: $1-73$

Walsh, J. J. (1981). Shelf-sea ecosystems. In: Longhurst, A. R. (ed.) Analysis of marine ecosystems. Academic Press, New York, p. 159-196 